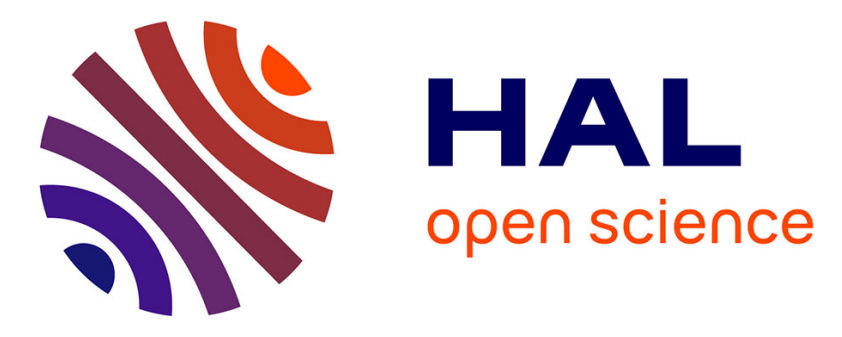

\title{
Benthic geochemistry of manganese in the Bay of Biscay, and sediment mass accumulation rate
}

\author{
A. Mouret, Pierre Anschutz, Pascal Lecroart, Gwénaëlle Chaillou, Christelle \\ Hyacinthe, Jonathan Deborde, Frans Jorissen, Bruno Deflandre, Sabine \\ Schmidt, Jean-Marie Jouanneau
}

\section{To cite this version:}

A. Mouret, Pierre Anschutz, Pascal Lecroart, Gwénaëlle Chaillou, Christelle Hyacinthe, et al.. Benthic geochemistry of manganese in the Bay of Biscay, and sediment mass accumulation rate. Geo-Marine Letters, 2009, 29 (3), pp.133-149. 10.1007/s00367-008-0130-6 . hal-03278057

\section{HAL Id: hal-03278057 \\ https://univ-angers.hal.science/hal-03278057}

Submitted on 5 Jul 2021

HAL is a multi-disciplinary open access archive for the deposit and dissemination of scientific research documents, whether they are published or not. The documents may come from teaching and research institutions in France or abroad, or from public or private research centers.
L'archive ouverte pluridisciplinaire HAL, est destinée au dépôt et à la diffusion de documents scientifiques de niveau recherche, publiés ou non, émanant des établissements d'enseignement et de recherche français ou étrangers, des laboratoires publics ou privés. 


\title{
Benthic geochemistry of manganese in the Bay of Biscay, and sediment mass accumulation rate
}

\author{
Aurélia Mouret • Pierre Anschutz • Pascal Lecroart • \\ Gwénaëlle Chaillou • Christelle Hyacinthe • \\ Jonathan Deborde • Frans J. Jorissen • \\ Bruno Deflandre • Sabine Schmidt • \\ Jean-Marie Jouanneau
}

Received: 10 July 2008 /Accepted: 14 November 2008 /Published online: 30 November 2008

(C) Springer-Verlag 2008

\begin{abstract}
Manganese is a major redox reactive element of benthic metabolism. We have built a database of existing knowledge on the benthic geochemistry of Mn in the Bay of Biscay, in order to comprehensively assess the behaviour of $\mathrm{Mn}$ in a variety of environments during early diagenesis. The database contains vertical profiles of particulate and dissolved Mn species of 59 cores collected during 17 cruises between 1997 and 2006 at nine stations positioned
\end{abstract}

Electronic supplementary material The online version of this article (doi:10.1007/s00367-008-0130-6) contains supplementary material, which is available to authorized users.

A. Mouret $\cdot$ P. Anschutz $(\bowtie) \cdot$ P. Lecroart $\cdot$ G. Chaillou $\cdot$

J. Deborde $\cdot$ B. Deflandre $\cdot$ S. Schmidt $\cdot$ J.-M. Jouanneau

Université de Bordeaux,

CNRS, UMR 5805-EPOC,

33405 Talence, France

e-mail: p.anschutz@epoc.u-bordeaux1.fr

G. Chaillou

Département de Biologie, Chimie et Géographie,

Université du Québec à Rimouski,

G5L 3A1 Rimouski,

QC, Canada

C. Hyacinthe

Department of Marine Sciences, University of Georgia, Athens, GA 30602, USA

\section{F. J. Jorissen}

Laboratoire d'Etude des Bio-indicateurs Actuels et Fossiles (BIAF) UPRES EA 2644, Université d'Angers,

49045 Angers Cedex, France

B. Deflandre

Université Paris 7, Laboratoire de Géochimie des Eaux, IPGP,

75251 Paris, France between 140 and 4,800 m water depths. At all studied stations, Mn species follow the conventional distribution, where $\mathrm{Mn}(\mathrm{III}, \mathrm{IV})$ species are enriched in the oxic layer, and dissolved $\mathrm{Mn}$ is present in the anoxic sediments. A minor part of Mn-oxides originates from sedimenting particles. The major part is of diagenetic origin, and derives from the oxidation of upward-diffusing dissolved Mn(II). Mn-oxide inventories are higher at the deeper stations than at the shallower ones. This difference cannot be attributed to different sources of sedimenting particles, but it must depend on sedimentation rate and diagenetic processes. At depth, dissolved $\mathrm{Mn}$ (II) concentrations are constant. This probably reflects equilibrium with an authigenic $\mathrm{Mn}(\mathrm{II})$ phase, which is the ultimate phase into which $\mathrm{Mn}$ is fossilized. The Mn content of deeper anoxic sediments is similarly low in all the cores studied, associated with corresponding trends of $\mathrm{Mn}$ content in sedimenting particles of the Bay of Biscay. Bioturbation, rather than redox oscillations, can convey $\mathrm{Mn}(\mathrm{III}, \mathrm{IV})$ species downwards into the anoxic sediments where they are reduced, associated with a peak of dissolved Mn. Because dissolved Mn(II) is re-oxidized when it diffuses towards the oxic layer, the inventory of the diagenetic $\mathrm{Mn}(\mathrm{III}, \mathrm{IV})$ phase remains at steady state, especially at stations where the oxic layer is thick. It then becomes possible to calculate the residence time of diagenetic Mn(III,IV) particles within the oxic layer, using the upward-directed flux of pore water $\mathrm{Mn}(\mathrm{II})$. By applying this residence time to the accumulation of sediments within the oxic layer, we obtain the sediment mass accumulation rate. The values calculated for the sediments of the Bay of Biscay fit well with accumulation rates obtained from radionuclides or sediment traps. The method has also been validated with data collected in other marine sedimentary environments. 


\section{Introduction}

Manganese is the most abundant transition metal in natural environments, after iron. Manganese oxides and oxyhydroxides represent significant oxidants for organic carbon in marine sediments (Aller 1990, 1994; Canfield et al. 1993; Thamdrup et al. 1994). In marine oxygenated environments, manganese is present in the form of Mn(IV) oxides and Mn(III) oxyhydroxides (Post 1999). These oxidized forms of $\mathrm{Mn}$ are very reactive and have a strong capacity for the adsorption of trace metals (Murray 1975; Stumm and Morgan 1996). Pore water Mn(II) is produced upon Mn-oxide reduction, which is coupled either directly to organic carbon oxidation (Froehlich et al. 1979; Myers and Nealson 1988a) or indirectly via the oxidation of reduced solutes like $\mathrm{Fe}^{2+}$, sulphide, ammonia or organic acids (Stone 1987; Myers and Nealson 1988b; Burdige et al. 1992; Luther et al. 1997; Hulth et al. 1999; Anschutz et al. 2000; Schippers and Jørgensen 2001; Hyacinthe et al. 2001; Luther and Popp 2002).

Marine sediments commonly contain an oxic surface layer enriched in insoluble $\mathrm{Mn}(\mathrm{III}, \mathrm{IV})$ phases. Deeper, these oxides are reduced to soluble Mn(II) (Burdige 1993). Dissolved Mn(II) can diffuse upwards in pore waters across the oxic-anoxic boundary, and sometimes across the sediment-water interface, where it precipitates again in the form of Mn(III,IV) (Sundby and Silverberg 1985). Precipitation and adsorption on particles of upward-diffusing Mn(II) is a dominant phenomenon that enriches oxidized surface sediment in manganese (Sundby et al. 1981; van der Zee et al. 2001). Vertical profiles of dissolved manganese in pore waters often display a concentration maximum immediately below the oxic front, with a downward-directed gradient below the maximum. Precipitation of mixed $\mathrm{Ca}-\mathrm{Mn}$ carbonates, driven by increased alkalinity production, traps $\mathrm{Mn}$ (II) in anoxic sediments (Middleburg et al. 1987; Mucci 1988, 2004; Jakobsen and Postma 1989).

Transient-state diagenesis is the rule for most continental margin sediments (Sundby 2006). For manganese species, non-steady-state diagenesis can be recognized on single vertical profiles when, for example, the depth where upward-diffusing $\mathrm{Mn}$ (II) is oxidized does not correspond to the depth of maximum enrichment of $\mathrm{Mn}(\mathrm{III}, \mathrm{IV})$ phases. Bioturbation, or seasonal redox oscillations due to episodic organic matter sedimentation are the major causes of shortterm (days-months) transient profiles (Gehlen et al. 1997; Gobeil et al. 1997; Anschutz et al. 2000). Seasonality in the geochemical composition of suspended matter, especially in coastal environments, may also modify vertical Mn distribution (Dellwig et al. 2007). Changes in bottom water oxygen concentrations exert a strong control on the redox environment within surface sediments, and can induce the migration of redox boundaries and reaction fronts (Sundby
2006). Bioirrigation through burrows is also a significant process that can affect the flux of dissolved $\mathrm{Mn}(\mathrm{II})$ in coastal environments (Aller and Aller 1998).

Moreover, the transient- or steady-state behaviour of Mn in modern marine sediments depends on the timescale of observation. At a multi-annual timescale, steady-state diagenesis may be assumed for Mn species, particularly when bioturbation activity is moderate. At steady state, the flux of buried $\mathrm{Mn}$ corresponds to the mean flux of sedimenting Mn. Enrichment of Mn-oxide in the oxic layer is of diagenetic origin. Therefore, at steady state, the level of diagenetic Mn-oxide must be maintained constant, controlled by the flux of $\mathrm{Mn}$ to the sediment and by benthic metabolic processes. In other words, at steady state the residence time, or mean lifetime, of Mn-oxides within the enriched surface sediment layer must be constant. Consequently, the distribution of Mn species and estimation of residence time may be used as an independent method to estimate sediment mass accumulation rate (MAR). This concept needs to be examined by studying the distribution of the different phases of $\mathrm{Mn}$ in numerous sediment cores.

We have built a database that collates published information (Hyacinthe et al. 2001; Anschutz et al. 2002; Chaillou et al. 2002, 2003, 2006; Fontanier et al. 2002, 2003, 2005, 2006) and non-published data of vertical benthic profiles of dissolved and particulate manganese, and major diagenetic parameters in several fine-grained sedimentary environments of the Bay of Biscay. Also included are sporadic measurements of physicochemical properties of the water column and suspended particles. This unique database gives us the possibility to (1) compare the distributions of $\mathrm{Mn}$ species in different sedimentary environments, (2) examine the seasonal-annual variability of Mn-species distribution and (3) relate enrichment levels of Mn species to sediment MAR for this bay, as well as (4) strengthen universal relationships between reactive $\mathrm{Mn}$ species, an aspect otherwise not feasible if based on only a few cores.

\section{Materials and methods}

\section{Sampling}

The Bay of Biscay is located on the eastern side of the Northern Atlantic Ocean, influenced by oceanic waters from the North Atlantic Drift. Several rivers in France and Spain (the Loire, Charente, Gironde, Adour, Bidassoa and Nervion) feed the sedimentary basin. The Gironde and Loire rivers are presently the main sources of fine sediments to the continental margin (Jouanneau et al. 1998b).

The Bay of Biscay database consists of 104 studied cores, for which vertical profiles of redox-sensitive properties have 
been measured. The distribution of manganese was studied in 59 undisturbed cores collected at nine stations between 140 and 4,825 $\mathrm{m}$ water depths in the south-eastern part of the bay, on the Aquitaine continental slope (stations A, B, C, D and F), and in the north-eastern part, close to Cap Ferret canyon (stations H, I, 2 and 11; Fig. 1, Table 1), during 17 cruises from 1997 to 2006. Seasonal variations in benthic parameters were estimated at stations $\mathrm{A}, \mathrm{B}$ and $\mathrm{D}$, which were sampled more than ten times in different seasons. Other stations were sampled less frequently. The deepest stations are influenced by North Atlantic deep water (NADW) with a temperature of $4^{\circ} \mathrm{C}$, those shallower than $1,200 \mathrm{~m}$ by warmer Mediterranean outflow water and Northern Atlantic central water (about $10-12^{\circ} \mathrm{C}$ ). At all stations, the sediments consist of mud composed of silico-clastic clay and silt, and less than $30 \%$ carbonates (Hyacinthe et al. 2001). Water column samples were taken in February 2002 and March 2003 at stations $\mathrm{A}, \mathrm{B}$ and $\mathrm{D}$.

\section{Material}

Cores were collected with a Barnett multi-corer, which enabled us to sample the upper few decimetres of the sediments, the overlying bottom water, and the undisturbed sediment-water interface. The cores were sliced in thin horizontal sections (generally, $0.5 \mathrm{~cm}$ thick for the top $2 \mathrm{~cm}$, $1 \mathrm{~cm}$ thick down to $8 \mathrm{~cm}$, and $2 \mathrm{~cm}$ thick below this). For each depth interval, a sub-sample was immediately sealed in a pre-weighed vial, and frozen for subsequent analyses of
Table 1 Study site characteristics

\begin{tabular}{lllr}
\hline Station & \multicolumn{2}{c}{ Geographical position } & Water depth (m) \\
\hline $\mathrm{A}$ & $44^{\circ} 10.24^{\prime} \mathrm{N}$ & $2^{\circ} 20.06^{\prime} \mathrm{W}$ & 1,000 \\
$\mathrm{~B}$ & $43^{\circ} 50.31^{\prime} \mathrm{N}$ & $2^{\circ} 03.47^{\prime} \mathrm{W}$ & 550 \\
$\mathrm{C}$ & $43^{\circ} 40.08^{\prime} \mathrm{N}$ & $1^{\circ} 38.87^{\prime} \mathrm{W}$ & 250 \\
$\mathrm{D}$ & $43^{\circ} 42.00^{\prime} \mathrm{N}$ & $1^{\circ} 33.45^{\prime} \mathrm{W}$ & 140 \\
$\mathrm{~F}$ & $44^{\circ} 17.10^{\prime} \mathrm{N}$ & $2^{\circ} 44.95^{\prime} \mathrm{W}$ & 1,250 \\
11 & $44^{\circ} 30^{\prime} \mathrm{N}$ & $2^{\circ} 40^{\prime} \mathrm{W}$ & 1,600 \\
$\mathrm{H}$ & $44^{\circ} 32.52^{\prime} \mathrm{N}$ & $3^{\circ} 37.23^{\prime} \mathrm{W}$ & 2,000 \\
$\mathrm{I}$ & $44^{\circ} 49.46^{\prime} \mathrm{N}$ & $2^{\circ} 33.78^{\prime} \mathrm{W}$ & 2,800 \\
2 & $45^{\circ} 30^{\prime} \mathrm{N}$ & $6^{\circ} 30^{\prime} \mathrm{W}$ & 4,825 \\
\hline
\end{tabular}

porosity and solid fraction. Another sub-sample was centrifuged under inert $\mathrm{N}_{2}$ atmosphere at $5,000 \mathrm{rpm}$ for $15 \mathrm{~min}$ in order to collect pore waters. A part of the supernatant was filtered $(0.2-\mu \mathrm{m}$ cellulose acetate syringe filter) and acidified with ultrapure $\mathrm{HNO}_{3}$ for dissolved $\mathrm{Mn}$ analyses.

Occasionally, surface sediments from a sister core were collected for excess ${ }^{210} \mathrm{~Pb}\left({ }^{210} \mathrm{~Pb}_{\mathrm{xs}}\right)$ and excess ${ }^{234} \mathrm{Th}$ $\left({ }^{234} \mathrm{Th}_{\mathrm{xs}}\right)$ analyses.

Water column samples were taken using a multi-sampler/ carousel with 12 bottles (12 l each), at depths close to the bottom ( $5 \mathrm{~m}$ above the seafloor), and at intermediate depths. Two or three bottles were sampled at each depth in order to collect enough suspended particles. The material was filtered on board through pre-weighed $0.4-\mu \mathrm{m}$ cellulose acetate membranes for selective leaching to extract reactive Mn-oxides.
Fig. 1 Map of the south-eastern part of the Bay of Biscay, showing the locations of the stations (squares)

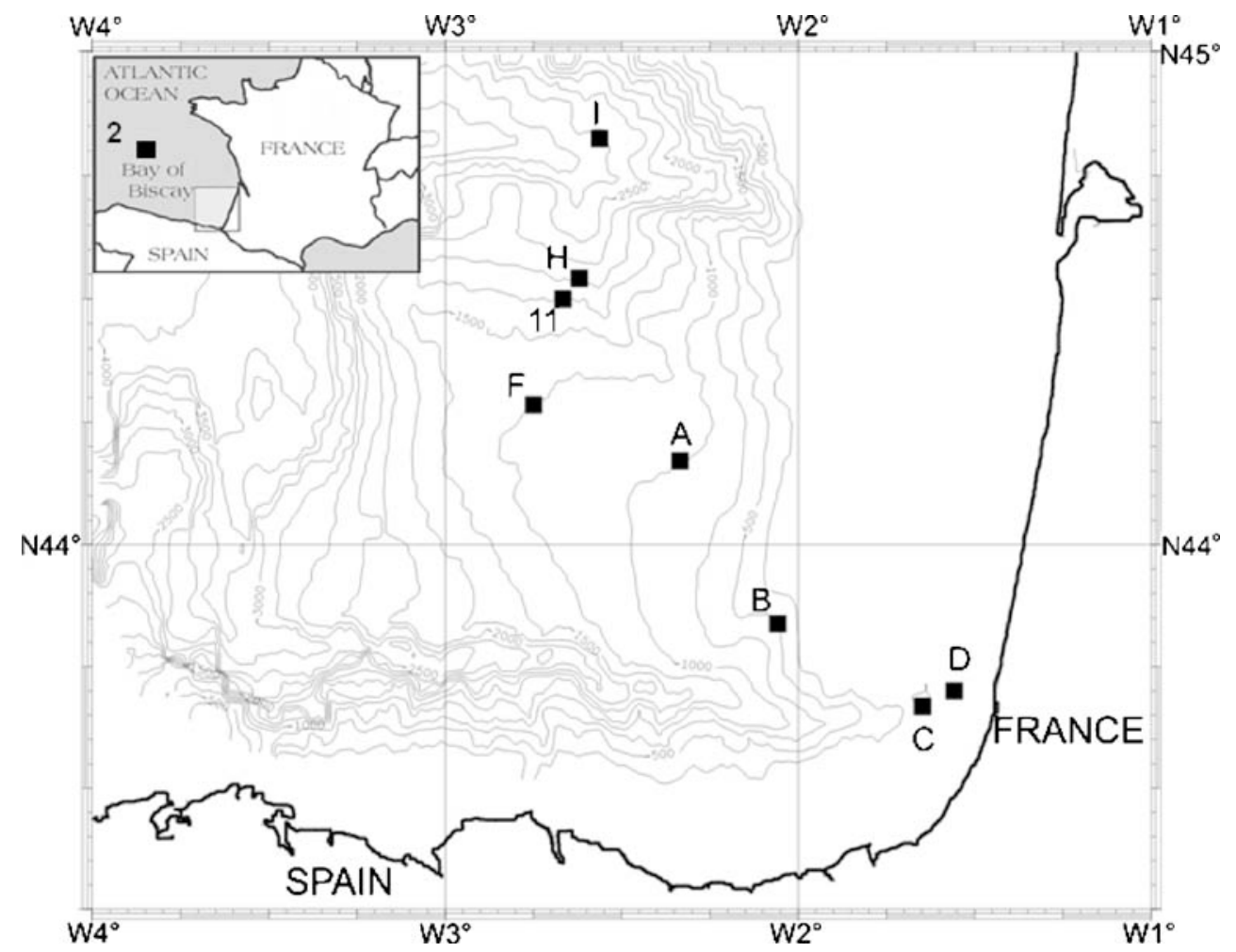


Analyses

Porosity was calculated from water content determined by comparison of the weights of wet and freeze-dried sediments. The specific density of whole particles was estimated at 2.65 (Berner 1980), which is the mean density of alumino-silicate and calcium carbonate minerals. Each freeze-dried solid fraction was homogenized, and the water content used to correct for the presence of sea salt.

Solid-phase samples were subjected to two different extraction techniques for the determination of reactive solid-phase $\mathrm{Mn}$. The most reducible fraction was extracted with an ascorbate solution $\left(50 \mathrm{~g} \mathrm{NaHCO}_{3}, 50 \mathrm{~g}\right.$ Na-citrate, $20 \mathrm{~g}$ ascorbic acid for 11 solution, buffered at $\mathrm{pH}$ 8; Kostka and Luther 1994; Anschutz et al. 2005). Another extraction on a separate aliquot was carried out with $1 \mathrm{~N} \mathrm{HCl}$ to determine acid-soluble $\mathrm{Mn}(\mathrm{Mn}-\mathrm{HCl})$. We had tested for any influence of sediment pre-treatment by performing extractions on freeze-dried, on frozen but not dried, and on fresh sediment. The selective leaching solutions eventually extracted almost the same quantity of particulate $\mathrm{Mn}$ in the three cases. Consequently, we decided to work on dried samples, because the control on particle weight was much better than for wet sediments.

For the ascorbate and $1 \mathrm{~N} \mathrm{HCl}$ procedures, about $100 \mathrm{mg}$ of dried sample was leached with $10 \mathrm{ml}$ solution during $24 \mathrm{~h}$, shaking continuously at ambient temperature. The supernatant was diluted with $0.2 \mathrm{M} \mathrm{HCl}$ for the ascorbate extraction, and with water for the $\mathrm{HCl}$ extraction. Manganese was measured by flame atomic absorption spectrometry (Perkin Elmer AA 300), using an external aqueous standard for calibration. The reproducibility of analyses was better than $5 \%$. $\mathrm{Mn}-\mathrm{HCl}$ represents the whole fraction of Mn-oxides and $\mathrm{Mn}$ associated with carbonates. $\mathrm{Mn}$ extracted with ascorbate (Mn-Asc) is only the most reducible part of $\mathrm{Mn}(\mathrm{III}, \mathrm{IV})$ oxides and oxyhydroxides.

$\mathrm{Mn}-\mathrm{Asc}$ and $\mathrm{Mn}-\mathrm{HCl}$ inventories were calculated from depth $a$ to depth $b$ according to

$I=\sum_{a}^{b} C_{z} \times\left(1-\phi_{z}\right) \times \Delta_{z} \times \rho$

where $I$ is the inventory of Mn-Asc or $\mathrm{Mn}-\mathrm{HCl}, \Delta_{z}$ the depth interval between depths $a$ and $b, C_{z}$ the Mn-Asc or $\mathrm{Mn}-\mathrm{HCl}$ concentration for $\Delta_{\mathrm{z}}, \phi_{z}$ the porosity for $\Delta_{\mathrm{z}}$, and $\rho$ the particle density. All inventories were integrated for the upper $20-\mathrm{cm}$ sediment column. This depth was chosen because it corresponds to the minimum length of the cores. The results show that for a $1-\mathrm{cm}^{2}$ horizontal core section, a $20-\mathrm{cm}$ depth column represents a rather constant sediment inventory. The values vary between about $12 \mathrm{~g}$ at stations $\mathrm{D}$ and $\mathrm{C}$, where mean porosity is highest, and $16 \mathrm{~g}$ at stations $\mathrm{A}, \mathrm{F}$ and 11.
Other properties related to early diagenesis of the sediment cores, which are included in the database but not all shown here (e.g. dissolved oxygen concentrations), have been analyzed according to methods described in detail elsewhere (Hyacinthe et al. 2001; Anschutz et al. 2002; Chaillou et al. 2002).

Maximum sediment mass accumulation rates and biodiffusion coefficients were estimated from vertical profiles of ${ }^{210} \mathrm{~Pb}_{\mathrm{xs}}$ (half-life $=22.3$ years) and ${ }^{234} \mathrm{Th}_{\mathrm{xs}}$ (half-life $=$ 24.1 days). Activities of ${ }^{210} \mathrm{~Pb}$ and of its parent ${ }^{226} \mathrm{Ra}$ were determined in about $5 \mathrm{~g}$ of freeze-dried material sealed in a counting vial, by high-resolution and low-background gamma spectrometry with a semiplanar and a well-type detector for 4-24 h (Jouanneau et al. 1998a; Schmidt et al. 2007). The $\gamma$ detectors were intercalibrated with IAEA reference materials (RGU-1 and RGTh-1). Supported ${ }^{210} \mathrm{~Pb}$ was determined by three independent methods, which gave the same result within the counting errors: (1) average ${ }^{210} \mathrm{~Pb}$ activities were estimated in deeper sections of the cores (except at stations $\mathrm{C}$ and D), (2) ${ }^{226} \mathrm{Ra}$-supported ${ }^{210} \mathrm{~Pb}$ activities were estimated from direct measurements of ${ }^{226} \mathrm{Ra}$ activities by gamma counting and (3) ${ }^{226} \mathrm{Ra}$ activities were obtained from ${ }^{214} \mathrm{Bi}$ and ${ }^{214} \mathrm{~Pb}$. By subtracting the activity of ${ }^{226} \mathrm{Ra}$ from the ${ }^{210} \mathrm{~Pb}$ total specific activity, we obtained the unsupported ${ }^{210} \mathrm{~Pb}$ component and used this to determine accumulation rates.

The uppermost sediment layers were measured for ${ }^{234} \mathrm{Th}$ by counting the $63.3 \mathrm{KeV}$ gamma emission. These measurements had to be completed within 1 month after sampling, due to the rapid decay of ${ }^{234} \mathrm{Th}$. Sediment layers were investigated downcore until a rather constant ${ }^{234} \mathrm{Th}$ activity was reached, which was considered as the supported activity used to calculate the ${ }^{234} \mathrm{Th}_{\mathrm{xs}}$ data. ${ }^{234} \mathrm{Th}$ activities were corrected for radioactive decay occurring between sample collection and counting.

\section{Results}

At all stations, the concentration of bottom water oxygen is always above $190 \mu \mathrm{mol} \mathrm{I}^{-1}$. Oxygen penetration depth varies from $5 \mathrm{~mm}$ at the shallowest station $\mathrm{D}$ to $10 \mathrm{~cm}$ at the deepest station 2. Profiles of pore water oxygen are not shown here. For all studied cores, the depth where oxygen disappears corresponds to the depth interval where dissolved Mn appears (cf. Fig. 2).

Mn-Asc contents in suspended particles are always less than $2 \mu \mathrm{mol} \mathrm{\textrm {g } ^ { - 1 }}$ for water samples collected on the continental slope below $250 \mathrm{~m}$ water depth. Actually, the Mn-Asc contents of suspended particles measured in February 2002 and March 2003 are $2 \mu \mathrm{mol} \mathrm{g}^{-1}$ at station B and $1 \mu \mathrm{mol} \mathrm{g}^{-1}$ at station A. Each Mn-Asc profile in the sediment cores shows a subsurface maximum. Maximum 


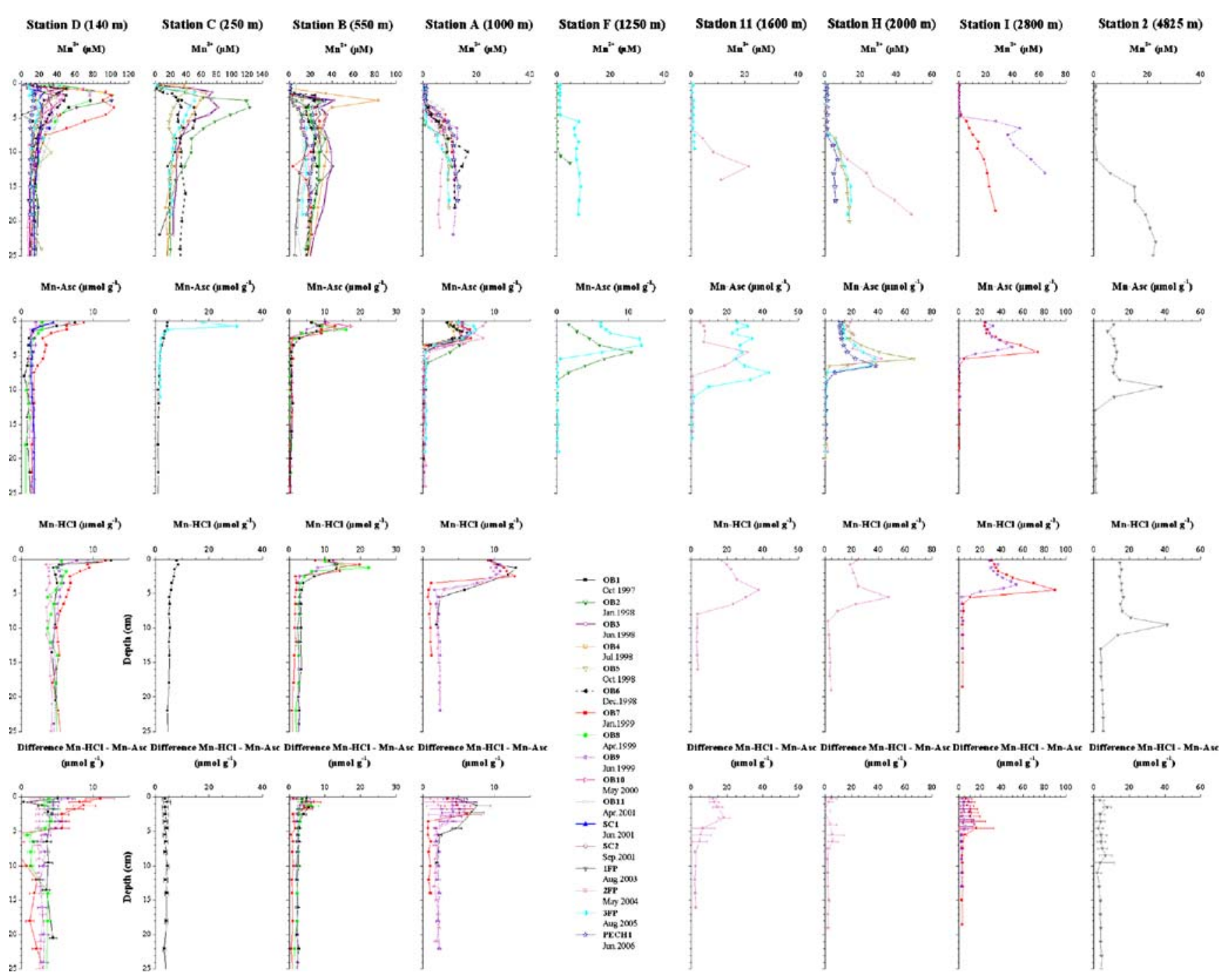

Fig. 2 Vertical depth (cm) profiles of pore water $\mathrm{Mn}\left(\mathrm{Mn}^{2+}, \mu \mathrm{M}\right), \mathrm{Mn}$ extracted by ascorbate (Mn-Asc, $\mu \mathrm{mol} \mathrm{g}^{-1}$ ), Mn extracted by $\mathrm{HCl}$ $\left(\mathrm{Mn}-\mathrm{HCl}, \mu \mathrm{mol} \mathrm{g}{ }^{-1}\right)$, and the difference between $\mathrm{Mn}-\mathrm{HCl}$ and $\mathrm{Mn}-$ Asc at stations D, C, B, A, F, 11, H, I and 2. Distinct symbols represent the different cruises during which cores were collected: legend: $O B$ Oxybent, $S C$ Sedican, $F P$ Foramprox cruises. The oxygen penetration depth of each core is contained in the sample where

values are above $30 \mu \mathrm{mol} \mathrm{g}^{-1}$ dry sediments for the deeper stations in contact with NADW, whereas the contents are lower than $20 \mu \mathrm{mol} \mathrm{g}^{-1}$ for the shallower stations (Fig. 2; the full dataset for this figure is available online in the electronic supplementary material for this article). Mn-Asc content is always higher in surface sediments than in suspended particles. For almost all stations, Mn-Asc contents decrease abruptly below the oxic front, and reach values close to zero. At the shallowest stations D and C, reactive Mn-oxides occur below the top of the anoxic sediments.

$\mathrm{Mn}-\mathrm{HCl}$ profiles show similar trends but $\mathrm{Mn}-\mathrm{HCl}$ contents are 2 to $5 \mu \mathrm{mol} \mathrm{g}^{-1}$ higher than Mn-Asc contents. The difference between the $\mathrm{Mn}-\mathrm{HCl}$ and $\mathrm{Mn}$-Asc values is close to $\mathrm{Mn}-\mathrm{HCl}$ at the bottom of the studied cores (Fig. 2). dissolved $\mathrm{Mn}(\mathrm{II})$ concentration begins to increase. The error on $\mathrm{Mn}$ $\mathrm{HCl}$ and $\mathrm{Mn}$-Asc values is about $10 \%$ but not indicated here, for better readability. The sum of the error bars for the difference between $\mathrm{Mn}-\mathrm{HCl}$ and $\mathrm{Mn}$-Asc represents the sum of errors on $\mathrm{Mn}-\mathrm{HCl}$ and $\mathrm{Mn}$-Asc. The full dataset is available online in the electronic supplementary material for this article

$\mathrm{Mn}-\mathrm{Asc}$ and $\mathrm{Mn}-\mathrm{HCl}$ inventories are reported in Tables 2 and 3, and the difference between $\mathrm{Mn}-\mathrm{HCl}$ and $\mathrm{Mn}-\mathrm{Asc}$ (cf. mainly $\mathrm{Mn}$ associated with carbonates) in Table 4. Sediments collected above 1,250 m water depth have Mn-Asc inventories of between 8 and $30 \mu \mathrm{mol} \mathrm{per} \mathrm{cm}^{2}\left(\mu \mathrm{mol} \mathrm{cm}{ }^{-2}\right)$ for a 20 -cm-long core, the values being between 110 and $166 \mu \mathrm{mol} \mathrm{cm}{ }^{-2}$ for the deeper stations. Sediments collected above $1,250 \mathrm{~m}$ water depth have $\mathrm{Mn}-\mathrm{HCl}$ inventories of between 30 and $80 \mu \mathrm{mol} \mathrm{cm}{ }^{-2}$, whereas the deeper stations have values between 130 and $190 \mu \mathrm{mol} \mathrm{cm}{ }^{-2}$. The inventories of $\mathrm{Mn}$ associated with the $\mathrm{Mn}-\mathrm{HCl}$ minus $\mathrm{Mn}$ Asc fractions are approx. constant $\left(40 \pm 20 \mu \mathrm{mol} \mathrm{cm}{ }^{-2}\right)$.

Dissolved manganese concentrations are less than $2 \mu \mathrm{moll}^{-1}$ in the oxic sediments. At the deeper stations, $\mathrm{Mn}^{2+}$ 
Table $2 \mathrm{Mn}-\mathrm{HCl}$ inventories ( $\mu \mathrm{mol} \mathrm{cm}^{-2} ; S D$ standard deviation)

\begin{tabular}{|c|c|c|c|c|c|c|c|c|}
\hline \multirow[t]{2}{*}{ Cruise } & \multicolumn{8}{|l|}{ Station } \\
\hline & $\begin{array}{l}\mathrm{D} \\
(140 \mathrm{~m})\end{array}$ & $\begin{array}{l}\mathrm{C} \\
(250 \mathrm{~m})\end{array}$ & $\begin{array}{l}\mathrm{B} \\
(550 \mathrm{~m})\end{array}$ & $\begin{array}{l}\text { A } \\
(1,000 \mathrm{~m})\end{array}$ & $\begin{array}{l}11 \\
(1,600 \mathrm{~m})\end{array}$ & $\begin{array}{l}\mathrm{H} \\
(2,000 \mathrm{~m})\end{array}$ & $\begin{array}{l}\text { I } \\
(2,800 \mathrm{~m})\end{array}$ & $\begin{array}{l}2 \\
(4,825 \mathrm{~m})\end{array}$ \\
\hline OB1 & 69.0 & 71.5 & 58.4 & 60.9 & - & - & - & - \\
\hline OB7 & 71.0 & - & 36.8 & 35.5 & - & - & 192.6 & - \\
\hline OB8 & 66.6 & - & 50.3 & - & - & - & - & - \\
\hline OB9 & 63.3 & - & 47.8 & 54.9 & - & - & 145.6 & - \\
\hline $1 \mathrm{FP}$ & - & - & - & - & - & - & - & 181.2 \\
\hline $2 \mathrm{FP}$ & 63.2 & - & - & 50.6 & 132.5 & 130.1 & - & - \\
\hline Average & 66.6 & 71.5 & 48.3 & 50.5 & 132.5 & 130.1 & 169.1 & 181.2 \\
\hline SD & $5 \%$ & - & $16 \%$ & $19 \%$ & - & - & $14 \%$ & - \\
\hline
\end{tabular}

concentration increases below the oxic layer and then reaches an almost constant value, between 10 and $20 \mu \mathrm{mol} \mathrm{l}^{-1}$. At the shallower stations, where Mn-Asc was detected in the anoxic sediments, $\mathrm{Mn}^{2+}$ profiles show a maximum below the oxic layer, with values reaching $100 \mu \mathrm{mol} \mathrm{l}^{-1}$. In the deeper anoxic zone, concentrations are close to $20 \mu \mathrm{mol} \mathrm{l}^{-1}$.

We observe a very similar overall shape for Mn-species profiles from cores collected in different months-years at a given station. However, the profiles are not identical. The difference becomes significant at the deeper stations, such as in replicate cores at stations F, 11 and H (Fig. 2). Here, two cores each collected during a different cruise to a given station can be situated several hundreds of meters apart because of ship drifting during multi-corer deployment. Thus, the seven cores studied for stations F, 11 and $\mathrm{H}$ can be considered as representing seven distinct sites. For clarity, the profiles have been grouped by station on Fig. 2.

At the shallower stations, like stations $\mathrm{D}$ and $\mathrm{C}$, vertical ${ }^{210} \mathrm{~Pb}_{\mathrm{xs}}$ profiles show almost no gradient (Fig. 3). At the deeper stations, by contrast, surface ${ }^{210} \mathrm{~Pb}_{\mathrm{xs}}$ activities are close to $1,000 \mathrm{~Bq} \mathrm{~kg}^{-1}$, and the values decrease exponentially downcore to reach less than $100 \mathrm{~Bq} \mathrm{~kg}^{-1}$ at depths varying between $2 \mathrm{~cm}$ at station 2 and $10 \mathrm{~cm}$ at station $\mathrm{B}$. A distinct deviation in the gradient occurs at about $1 \mathrm{~cm}$ depth in the profiles of stations A and B.

Activities of ${ }^{234} \mathrm{Th}_{\mathrm{xs}}$, measured in the surface layers of the cores (Table 5), decrease strongly with depth, to below the detection limit at $1 \mathrm{~cm}$ depth for most of the cores. The values recorded in the upper $0.5 \mathrm{~cm}$ vary from cruise to cruise at a given station.

Table 3 Mn-Asc inventories ( $\mu \mathrm{mol} \mathrm{cm}{ }^{-2} ; S D$ standard deviation)

\begin{tabular}{|c|c|c|c|c|c|c|c|c|c|}
\hline \multirow[t]{2}{*}{ Cruise } & \multicolumn{9}{|l|}{ Station } \\
\hline & $\begin{array}{l}\mathrm{D} \\
(140 \mathrm{~m})\end{array}$ & $\begin{array}{l}\mathrm{C} \\
(250 \mathrm{~m})\end{array}$ & $\begin{array}{l}\text { B } \\
(550 \mathrm{~m})\end{array}$ & $\begin{array}{l}\text { A } \\
(1,000 \mathrm{~m})\end{array}$ & $\begin{array}{l}\mathrm{F} \\
(1,250 \mathrm{~m})\end{array}$ & $\begin{array}{l}11 \\
(1,600 \mathrm{~m})\end{array}$ & $\begin{array}{l}\mathrm{H} \\
(2,000 \mathrm{~m})\end{array}$ & $\begin{array}{l}\text { I } \\
(2,800 \mathrm{~m})\end{array}$ & $\begin{array}{l}2 \\
(4,825 \mathrm{~m})\end{array}$ \\
\hline OB1 & 14.5 & 19.3 & 19.0 & 12.7 & - & - & - & - & - \\
\hline OB2 & - & - & - & 15.7 & 23.0 & - & - & - & - \\
\hline OB3 & - & - & - & 12.5 & - & - & - & - & - \\
\hline OB4 & - & - & - & 8.1 & - & - & - & - & - \\
\hline OB5 & - & - & - & 11.7 & - & - & 118.5 & - & - \\
\hline OB6 & - & - & - & 8.7 & - & - & - & - & - \\
\hline OB7 & 27.8 & - & 18.0 & 13.9 & - & - & - & 123.9 & - \\
\hline OB8 & 15.2 & - & 14.6 & - & - & - & - & - & - \\
\hline OB9 & 20.7 & - & 14.3 & 15.1 & - & - & - & 100.1 & - \\
\hline OB10 & - & - & 19.2 & 13.9 & - & - & - & - & - \\
\hline OB11 & - & - & - & 11.3 & - & - & - & - & - \\
\hline SC1 & 20.3 & - & - & - & - & - & - & - & - \\
\hline $1 \mathrm{FP}$ & - & - & - & - & - & - & - & - & 124.5 \\
\hline $2 \mathrm{FP}$ & 20.5 & - & - & 18.9 & - & 111.2 & 96.3 & - & - \\
\hline $3 \mathrm{FP}$ & - & 28.9 & - & 16.4 & 27.6 & 166.9 & 109.1 & - & - \\
\hline PECH1 & - & - & - & - & - & - & 91.0 & - & - \\
\hline Average & 19.8 & 24.1 & 17.0 & 13.2 & 25.3 & 139.1 & 103.7 & 112.0 & 124.5 \\
\hline SD & $22 \%$ & $20 \%$ & $13 \%$ & $22 \%$ & $9 \%$ & $20 \%$ & $10 \%$ & $11 \%$ & - \\
\hline
\end{tabular}


Table $4 \mathrm{Mn}-\mathrm{HCl}$ minus $\mathrm{Mn}$-Asc inventories $\left(\mu \mathrm{mol} \mathrm{cm} \mathrm{cm}^{-2}\right)$

\begin{tabular}{|c|c|c|c|c|c|c|c|c|}
\hline \multirow[t]{2}{*}{ Cruise } & \multicolumn{8}{|l|}{ Station } \\
\hline & $\begin{array}{l}\mathrm{D} \\
(140 \mathrm{~m})\end{array}$ & $\begin{array}{l}\mathrm{C} \\
(250 \mathrm{~m})\end{array}$ & $\begin{array}{l}\mathrm{B} \\
(550 \mathrm{~m})\end{array}$ & $\begin{array}{l}\text { A } \\
(1,000 \mathrm{~m})\end{array}$ & $\begin{array}{l}11 \\
(1,600 \mathrm{~m})\end{array}$ & $\begin{array}{l}\mathrm{H} \\
(2,000 \mathrm{~m})\end{array}$ & $\begin{array}{l}\mathrm{I} \\
(2,800 \mathrm{~m})\end{array}$ & $\begin{array}{l}2 \\
(4,825 \mathrm{~m})\end{array}$ \\
\hline OB1 & 54 & 52 & 39 & 48 & - & - & - & - \\
\hline OB7 & 43 & - & 19 & 22 & - & - & 69 & - \\
\hline OB8 & 51 & - & 36 & - & - & - & - & - \\
\hline OB9 & 42 & - & 33 & 40 & - & - & 45 & - \\
\hline $1 \mathrm{FP}$ & - & - & - & - & - & - & - & 57 \\
\hline $2 \mathrm{FP}$ & 43 & - & - & 32 & 21 & 34 & - & - \\
\hline Average & 47 & 52 & 32 & 36 & 21 & 34 & 57 & 57 \\
\hline
\end{tabular}
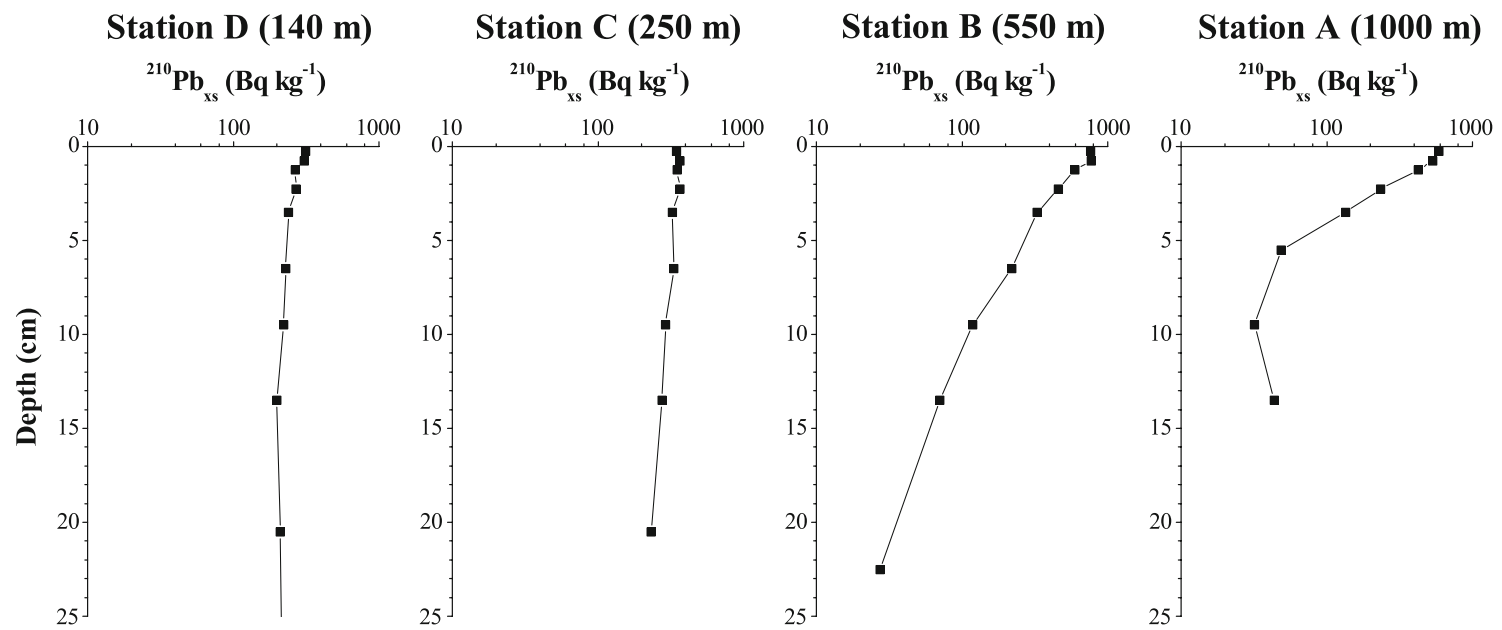

Station H (2000 m)

Station I (2800 m)

Station $2(4826 \mathrm{~m})$

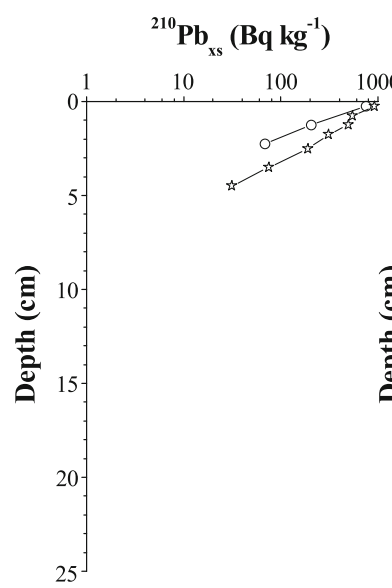

${ }^{210} \mathrm{~Pb}_{\mathrm{xs}}\left(\mathrm{Bq} \mathrm{kg}{ }^{-1}\right)$

${ }^{210} \mathrm{~Pb}_{\mathrm{xs}}\left(\mathrm{Bq} \mathrm{kg}^{-1}\right)$

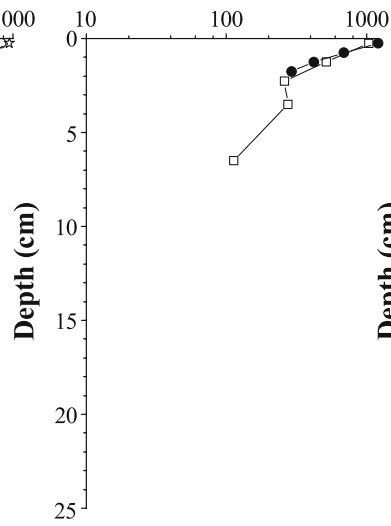

Fig. 3 Vertical profiles of $\log { }^{210} \mathrm{~Pb}_{\mathrm{xs}}\left(\mathrm{Bq} \mathrm{kg}^{-1}\right)$. The profiles at stations D, C, B and A (closed squares) were obtained from cores collected during the Oxybent 1 cruise. The open dots represent log ${ }^{210} \mathrm{~Pb}_{\mathrm{xs}}$ of surface sediments at station $\mathrm{H}$ collected during Oxybent 5 ,

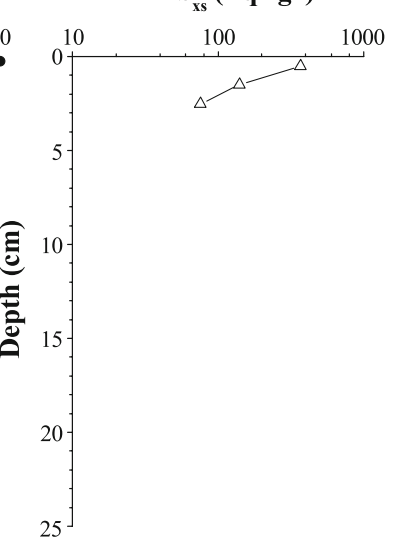

and open stars during Pech 1. At station I, open squares represent data from Oxybent 7, and closed dots from Oxybent 9. Station 2 was sampled during the Foramprox 1 cruise (open triangles) 
Table $5{ }^{234} \mathrm{Th}_{\mathrm{xs}}$ data used for the calculation of biodiffusion coefficients (see text; $n d$ not detected)

\begin{tabular}{|c|c|c|}
\hline Cruise & $\begin{array}{l}\text { Depth } \\
(\mathrm{cm})\end{array}$ & $\begin{array}{l}{ }^{234} \mathrm{Th}_{\mathrm{xs}} \\
\left(\mathrm{Bq} \mathrm{kg}^{-1}\right)\end{array}$ \\
\hline \multicolumn{3}{|c|}{ Station B $(550 \mathrm{~m})$} \\
\hline OB1 & $\begin{array}{l}0-0.50 \\
0.50-1.00\end{array}$ & $\begin{array}{l}110 \\
33\end{array}$ \\
\hline OB2 & $\begin{array}{l}0-0.25 \\
0.25-0.50 \\
0.50-0.75 \\
0.75-1.00\end{array}$ & $\begin{array}{l}2,704 \\
325 \\
538 \\
118\end{array}$ \\
\hline OB8 & $\begin{array}{l}0-0.50 \\
0.50-1.00\end{array}$ & $\begin{array}{l}801 \\
66\end{array}$ \\
\hline \multicolumn{3}{|c|}{ Station A $(1,000 \mathrm{~m})$} \\
\hline OB1 & $\begin{array}{l}0-0.50 \\
0.50-1.00\end{array}$ & $\begin{array}{l}270 \\
32\end{array}$ \\
\hline OB2 & $\begin{array}{l}0-0.50 \\
0.50-1.00 \\
1-2\end{array}$ & $\begin{array}{l}375 \\
237 \\
80\end{array}$ \\
\hline OB3 & $\begin{array}{l}0-0.50 \\
0.50-1.00\end{array}$ & $\begin{array}{l}102 \\
\text { nd }\end{array}$ \\
\hline OB10 & $\begin{array}{l}0-0.50 \\
0.50-1.00\end{array}$ & $\begin{array}{l}407 \\
107\end{array}$ \\
\hline Station & & \\
\hline OB7 & $\begin{array}{l}0-0.50 \\
0.50-1.00\end{array}$ & $\begin{array}{l}312 \\
\text { nd }\end{array}$ \\
\hline OB9 & $\begin{array}{l}0-0.50 \\
0.50-1.00\end{array}$ & $\begin{array}{l}263 \\
\text { nd }\end{array}$ \\
\hline OB10 & $\begin{array}{l}0-0.50 \\
0.50-1.00\end{array}$ & $\begin{array}{l}451 \\
341\end{array}$ \\
\hline
\end{tabular}

\section{Discussion and conclusions}

Transport process characterization

Bioturbation is classically described as an eddy-diffusive transport process occurring within a surface mixed layer
(Goldberg and Koide 1962). Biodiffusion is a local transport associated with spatially random and small-scale sediment displacements between discrete mixing events (Boudreau 1986a; Meysman et al. 2003). Nonlocal mixing, which implies the exchange of material between non-adjacent points, can exist in natural environments (Boudreau 1986b) but, due to the absence of peaks along the radiogenic profiles reported for the present study (Fig. 3), this process is not considered further in this case.

Surface sediments can be characterized by a mixed layer of thickness $L$ with both a constant biodiffusion coefficient $(\mathrm{Db})$ and a constant burial rate $(w)$. The mixed-layer depth is generally defined as the depth of strong slope inflection along the ${ }^{210} \mathrm{~Pb}$ profile. Biodiffusion coefficients are computed from ${ }^{234} \mathrm{Th}$ profiles (Table 6). Recently, Lecroart et al. (2007) reported that short-lived radioisotopes are highly suitable to constrain bioturbation in coastal and shelf sedimentary environments. At steady state, and assuming constant porosity, the classical advection-diffusion model equation adapted for short-lived radionuclides is used for the mixed layer:

$0=D b(t) \frac{\partial^{2} A}{\partial z^{2}}-w \frac{\partial A}{\partial z}-\lambda A$

where $A$ is the activity of the radionuclide within the mixed layer, $z$ the depth in the mixed layer relative to the sediment-water interface, and $\lambda$ the decay rate of ${ }^{234} \mathrm{Th}$ $\left(\lambda=10.51\right.$ year $\left.^{-1}\right)$. Solution of Eq. (2) enables computation of $\mathrm{Db}$ :

$$
D b=\frac{\lambda z^{2}}{\left[\ln \left(A(z) / A_{0}\right)\right]^{2}}+\frac{w z}{\ln \left(A(z) / A_{0}\right)}
$$

where $A_{0}$ is the activity of ${ }^{234} \mathrm{Th}$ at the sediment-water interface. $\mathrm{Db}$ can be characterized in terms of depth profiles of ${ }^{234} \mathrm{Th}$ if an independent tracer is used to compute the

Table 6 Burial rates and biodiffusion coefficients computed from ${ }^{210} \mathrm{~Pb}$ and ${ }^{234} \mathrm{Th}$

\begin{tabular}{|c|c|c|c|c|c|}
\hline & $\begin{array}{l}\text { Water depth } \\
\text { (m) }\end{array}$ & Cruise \# & $\begin{array}{l}\text { Burial rate } \\
\left(\mathrm{cm} \mathrm{year}^{-1}\right)\end{array}$ & $\begin{array}{l}\text { Mixed-layer depth } \\
(\mathrm{cm})\end{array}$ & $\begin{array}{l}\text { Biodiffusion coefficient } \\
\left(\mathrm{cm}^{2} \text { year }^{-1}\right)\end{array}$ \\
\hline Station D & 140 & OB1 & - & $>30$ & - \\
\hline Station C & 250 & OB1 & - & $>20$ & - \\
\hline \multirow[t]{4}{*}{ Station B } & 550 & OB1 & 0.120 & 1 & 1.80 \\
\hline & & OB2 & - & - & 0.80 \\
\hline & & OB8 & - & - & 0.40 \\
\hline & & OB10 & - & - & 14.80 \\
\hline \multirow[t]{4}{*}{ Station A } & 1,000 & OB1 & 0.062 & 1 & 0.56 \\
\hline & & OB2 & - & - & 6.70 \\
\hline & & OB3 & - & - & 0.12 \\
\hline & & OB10 & - & - & 1.45 \\
\hline \multirow[t]{3}{*}{ Station I } & 2,800 & OB7 & 0.045 & $<1$ & $<0.08$ \\
\hline & & OB9 & 0.033 & $<1$ & $<0.08$ \\
\hline & & OB10 & - & - & 0.55 \\
\hline
\end{tabular}


burial rate. Below the mixed layer, the ${ }^{210} \mathrm{~Pb}$ profile is affected only by burial and decay. At steady state, the conservation equation enables us to compute the burial rate

$w=-\frac{\lambda}{p}$

where $p$ is defined in a semi-logarithmic diagram by the slope of the ${ }^{210} \mathrm{~Pb}$ profile beneath the bioturbated layer.

At stations $\mathrm{C}$ and $\mathrm{D}$, the thickness of the bioturbated layer exceeds the length of the cores (Fig. 3, Table 6), meaning that bioturbation dominates over sedimentation, making it impossible to determine maximum MAR in this case. At the deepest stations (A, B and I), the bioturbated layer is thinner $(L \leq 1 \mathrm{~cm})$ than that commonly found in sedimentary environments (Boudreau 1998). This may be due to the high proportion of mostly refractory organic matter of terrestrial origin present at these stations (Etcheber et al. 1999; Grémare et al. 2005), which probably does not favour deep endomacrobenthic activity. The corresponding biodiffusion coefficients range from 0.08 to $14.8 \mathrm{~cm}^{2}$ year ${ }^{-1}$. Bioturbation could have slightly affected the manganese redox front at station B but less so at the other deep stations. Nevertheless, because the sediment could have been subjected to disturbance by burrowing organisms at all stations, ${ }^{210} \mathrm{~Pb}_{\mathrm{xs}}$ profiles may represent maximum accumulation rates.

To conclude, accumulation rates deduced from ${ }^{210} \mathrm{~Pb}_{\mathrm{xs}}$ and porosity profiles have maximum values of $80,36,14$, 17 and $20 \mathrm{mg} \mathrm{cm}^{-2}$ year $^{-1}$ at stations B, A, H, I and 2 respectively. Calculations of accumulation rates are less robust at stations $\mathrm{H}, \mathrm{I}$ and 2, because of the shortness of the ${ }^{210} \mathrm{~Pb}_{\mathrm{xs}}$ profiles. Grain size and calcium carbonate content are constant along cores collected at stations A, B, D and I (Hyacinthe et al. 2001), suggesting that mass accumulation rates can be assumed to be constant along the first decimetres of the sediment column of the Bay of Biscay slope.

Diagenetic recycling of $\mathrm{Mn}$ at the oxic-anoxic front

The ascorbate method enables us to extract bio-available Mn-oxides selectively, although it is not possible to differentiate between $\mathrm{Mn}(\mathrm{III})$ oxyhydroxides and $\mathrm{Mn}(\mathrm{IV})$ oxides (Hyacinthe and Van Cappellen 2004; Anschutz et al. 2005). The $1 \mathrm{~N} \mathrm{HCl}$ leaching method yields the ascorbateextractable fraction and $\mathrm{Mn}$ associated with acid-soluble phases, such as carbonates and hydrous aluminium silicates. The general shape of the $\mathrm{Mn}$-species profiles in sediments of the Bay of Biscay reflects the common vertical redox sequence observed in modern marine sediments. Manganese(III,IV) oxides extracted with ascorbate are present in the oxic layer, whereas dissolved $\mathrm{Mn}(\mathrm{II})$ becomes detectable in the anoxic sediments (Fig. 4). The

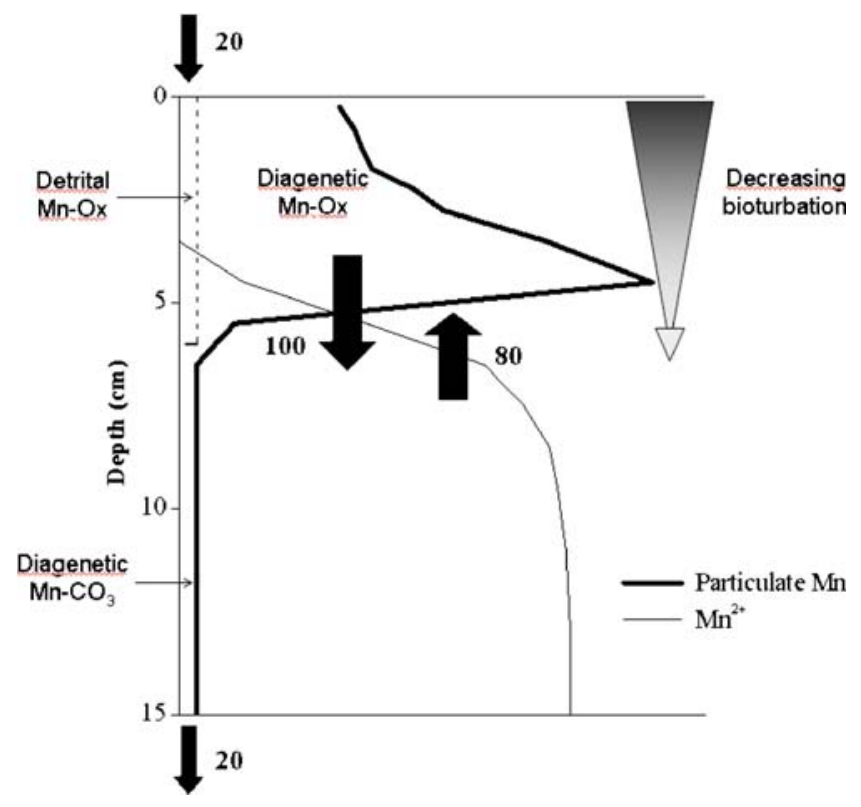

Fig. 4 Cycle of manganese in sediments of the Bay of Biscay. At steady state, the flux of buried $\mathrm{Mn}-\mathrm{HCl}$ is equal to the flux of settling detrital manganese oxides from the water column. The major part of the Mn-oxide pool is of diagenetic origin. This pool is at steady state. The downward flux of diagenetic Mn-oxides at the redox front is equal to the upward flux of $\mathrm{Mn}(\mathrm{II})$. Flux values in the figure are indicative, with an arbitrary unit

disappearance of $\mathrm{Mn}(\mathrm{III}, \mathrm{IV})$ species below the oxic layer is generally explained by their dissimilatory reduction by heterotrophic bacteria (Froehlich et al. 1979). The oxidation of $\mathrm{Mn}(\mathrm{II})$ with $\mathrm{O}_{2}$ explains the decrease in $\mathrm{Mn}(\mathrm{II})$ concentrations from the anoxic sediments to the oxic boundary. At steady state, when the redox front does not migrate relative to the sediment surface, the shape of Mnoxide profiles should show only one peak at the depth of the manganese redox front (Burdige and Gieskes 1983). Actually, our database reveals high Mn-Asc contents in the whole oxic zone for all profiles, and these cannot be explained by corresponding enrichment levels in settling particles (cf. the latter are substantially less enriched; see above). This points to essentially four alternative explanations, not necessarily mutually exclusive.

1. The Mn redox boundary and oxygen penetration depth may migrate within the Mn-oxide-enriched layer as a consequence of episodic fresh organic matter sedimentation. These redox fluctuations can redistribute $\mathrm{Mn}$ oxides in the oxic zone (Katsev et al. 2006).

2. Episodic bioirrigation through burrows may enable anoxic water advection to the oxic layer, where $\mathrm{Mn}$ (II) can be oxidized.

3. Mn-oxides may be mixed throughout the oxic layer by biological activity. Because of their stability under oxic conditions, they would accumulate in this depth interval. A relatively low level of bioturbation may 
suffice to redistribute Mn-oxide particles while maintaining a sharp gradient of Mn-Asc at the redox boundary, and a decreasing ${ }^{210} \mathrm{~Pb}_{\mathrm{xs}}$ slope.

4. Mn-oxide may be locally reduced to $\mathrm{Mn}$ (II) with ammonia produced by organic nitrogen mineralization within the oxic layer (Luther et al. 1997; Anschutz et al. 2000). It also can be reduced to dissolved Mn(III) (Trouwborst et al. 2006). Thus, local concentration of dissolved Mn could generate a short phase of diffusive transport before re-oxidation with oxygen to Mn-oxide. Repeated occurrence of this process could disperse the Mn-oxide pool uniformly in the oxic layer up to the sediment-water interface, without producing detectable peaks in dissolved Mn concentrations.

In cases 1 and 2, we would expect that at least a few of the studied cores would present evidence of significant dissolved $\mathrm{Mn}$ enrichment extending up to the Mn-oxide-enriched layer. Our database, comprising more than 30 cores collected at different places and times, and in which Mn-oxides and dissolved Mn were measured concurrently, reveals no indication of high dissolved Mn concentrations above the Mn-oxide maximum. Therefore, the bottom of the Mn-oxideenriched layer is probably the only depth where $\mathrm{Mn}$ (II) is oxidized. Explanation 4 suggests that some dissolved $\mathrm{Mn}$ crosses the sediment-water interface and escapes from the sediment. Below, we argue against sediment loss of Mn. Therefore, a low level of bioturbation may account for the uniformly high Mn-Asc levels recorded in the oxic layer of our cores.

$\mathrm{Mn}-\mathrm{HCl}$ at the bottom of the studied cores is probably representative of the reactive buried Mn fraction. At steady state, the content of buried $\mathrm{Mn}$ must be equal to that of settling detrital Mn-oxides (Fig. 4), especially at stations where the concentration of dissolved $\mathrm{Mn}$ (II) is close to zero in the oxic layer. At stations $\mathrm{B}$ and $\mathrm{A}$, the Mn-oxide contents of settling particles are very similar to the difference between the $\mathrm{Mn}-\mathrm{HCl}$ and $\mathrm{Mn}$-Asc pools of the anoxic sediment layer (Fig. 2). Therefore, $\mathrm{Mn}$ is probably at steady state at a multi-annual timescale.

Constant values of dissolved $\mathrm{Mn}$ recorded at depth in most of the cores can be explained by an equilibrium between the aqueous $\mathrm{Mn}$ (II) and an authigenic Mn phase. An increase in alkalinity due to sulphate reduction observed in the shallowest cores (Chaillou et al. 2003), and observations reported in the literature suggest that authigenic $\mathrm{Mn}$ associated with carbonate can represent the main phase under which reactive $\mathrm{Mn}$ is ultimately buried in anoxic sediments (Holdren et al. 1975; Grill 1978; Suess 1979; Aller 1980; Pedersen and Price 1982; Thomson et al. 1986; Middelburg et al. 1987; Mucci 1988, 2004; Jakobsen and Postma 1989). Under oxic conditions, authigenic Mn-carbonate precipitation is not favoured, because of low $\mathrm{Mn}$ enrichment and acidity produced by aerobic respiration (e.g. Jahnke et al. 1997). Although errors on the difference between the $\mathrm{Mn}-\mathrm{HCl}$ and Mn-Asc pools become high in the oxic layer, there is an enrichment of this fraction in the oxic zone at some stations (A, B and 11). Some refractory Mn-oxides that are not leachable with ascorbate but extracted by $\mathrm{HCl}$ may explain this excess. Adsorption of $\mathrm{Mn}$ (II) onto particles such as iron oxides also may enrich the oxic layer in extractible Mn (e.g. van der Zee et al. 2001).

To conclude, authigenic Mn-oxides precipitate close to the oxic-anoxic boundary and are advected via particle mixing. At depth, the reactive Mn content of the anoxic sediments corresponds to the Mn content of settling particles. Diagenetic Mn recycling at the oxic-anoxic front modifies $\mathrm{Mn}$ solid speciation but not Mn inventories.

\section{Shape of pore water $\mathrm{Mn}(\mathrm{II})$ profiles}

Dissolved Mn profiles exhibit different shapes depending on the presence or absence of Mn-Asc in the anoxic sediments. A dissolved Mn peak is present in the upper part of the anoxic layer when Mn-Asc occurs below the oxic layer. Such peaks can be built when the reductive dissolution of Mn-oxides exceeds the upward and downward Mn(II,III) diffusive fluxes triggered by $\mathrm{Mn}(\mathrm{II}, \mathrm{III})$ re-oxidation and authigenic carbonate formation respectively.

\section{Bioturbated (shallower) stations}

With strong bioturbation, as observed at the shallowest stations, significant amounts of Mn-oxides can be conveyed to the anoxic zone where they are reduced, resulting in a dissolved Mn(II) peak. A fraction of dissolved Mn may consist of transient Mn(III) (Trouwborst et al. 2006). When bioturbation is permanent, as at stations $\mathrm{C}$ and $\mathrm{D}$, this $\mathrm{Mn}$ (II) peak can persist (Fig. 2). Otherwise, such peaks would be temporary or less pronounced, as detected in some cores of station B.

The presence of Mn-oxide in the anoxic sediment layer could also be explained by an abrupt upward shift of the redox boundary (oxygen penetration depth, Mn redox boundary), which would "bury" the formerly active Mn spike into anoxic conditions (Katsev et al. 2006). Because the Mn peak was detected in all cores collected at stations D and C, the bioturbation scenario is more likely in the present case.

\section{Less bioturbated (deeper) stations}

At the deepest stations (A, F, H, 11, I and 2), the finding that several profiles show a gradual increase of dissolved Mn below the oxic layer (without a maximum concentration peak) suggests that manganese oxides are transported to the anoxic zone only by slow sedimentation. Oxides are 
reduced at the bottom of, or immediately below the oxic layer via heterotrophic bacterial respiration or by means of reduced compounds that diffuse from below, such as dissolved sulphide, iron or ammonia (Anschutz et al. 2002).

To conclude, an Mn(II) peak below the oxic zone can be an indication that bioturbation affects the anoxic part of the sediments. The fact remains that a part of reducible Mn must reach the anoxic sediments far below (several $\mathrm{cm}$ ) the oxicanoxic front in order to sustain the upward flux of dissolved $\mathrm{Mn}(\mathrm{II})$, and the formation of $\mathrm{Mn}$ associated with carbonates.

\section{Spatial heterogeneity of particulate Mn distribution}

Mn-Asc profiles can show temporal variations for a given station (Fig. 5a). We initially suspected that this was due largely to heterogeneous sub-sampling of cores. In a simple model, we calculated and drew the profiles of manganese oxides obtained for different resolutions of core slicing along a porosity gradient (Fig. 5b; details are given in the caption to this figure). The resulting profiles are very dissimilar from one slicing step to another, whereas the overall inventory of Mn-oxide is always the same. Thus, the shape of profiles is not appropriate to meaningfully compare site- and time-specific vertical distributions of a given species. Better would be to integrate the $\mathrm{Mn}$ inventory for each core, since the vertical slicing resolution varied during our sampling campaigns.

The data show that, at a given station, inventories of MnAsc and $\mathrm{Mn}-\mathrm{HCl}$ are of the same order of magnitude for the different sampling time periods. The standard deviation is always lower than $22 \%$ (Tables 2 and 3), and can largely be explained by a likely $20 \%$ error in manganese and porosity measurements. We can also hypothesize that such fluctuations could at least partly be due to transient-state processes. However, quantitative examination argues against this. For example, at station $\mathrm{A}$, the Mn-Asc inventory of the core collected during the Oxybent 4 cruise is $7.6 \pm 4.7 \mu \mathrm{mol} \mathrm{cm}{ }^{-2}$ higher than that for the core collected during Oxybent 2 (Table 2). Considering the maximum diffusive flux of dissolved $\mathrm{Mn}$ (II) at station A (Table 7), a diffusion time of $20 \pm 12$ years would be necessary to explain this enrichment in Mn-Asc, but the time span between the two cruises is only 7 months. On the other hand, spatial heterogeneities may well be important in this respect, since what we call "a station" in fact encompasses a relatively large area because of ship drifting during coring operations, particularly at the deepest stations. Indeed, in such deep-sea sampling campaigns, it is difficult to discriminate between patchiness and any temporal evolution trends (e.g. Fontanier et al. 2003).

Sediments collected above $1,250 \mathrm{~m}$ water depth have Mn-Asc inventories lower than for the deeper stations (Fig. 6). It is noteworthy that the deeper stations are located in the northern sector of the study area, so that this contrast with the southern stations could be due to differences in terrigeneous material sources. This hypothesis remains to be verified, because the assessment of terrigeneous material origin in the Bay of Biscay has to date focused only on the

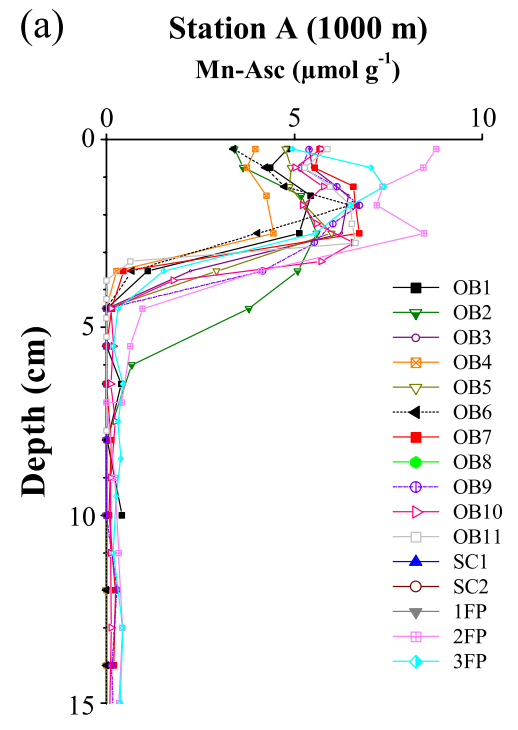

Fig. 5 a Mn-oxides (Mn-Asc) concentration profiles $\left(\mu \mathrm{mol} \mathrm{g}^{-1}\right)$ vs. depth at station A for the period 1997 to 2006. b Model of different ways of slicing a core. Thick black line Mn-Asc content profile tested in the model, slicing 1 slicing step of $0.5 \mathrm{~cm}$, slicing 2 initial slicing of $0.5 \mathrm{~cm}$ and then a step of $1 \mathrm{~cm}$, slicing 3 slicing step of $1 \mathrm{~cm}$ for the upper $2 \mathrm{~cm}$ of the core and of $2 \mathrm{~cm}$ for the remainder, slicing 4 initial slicing of $0.5 \mathrm{~cm}$ and then a step of $2 \mathrm{~cm}$. The resulting profiles are

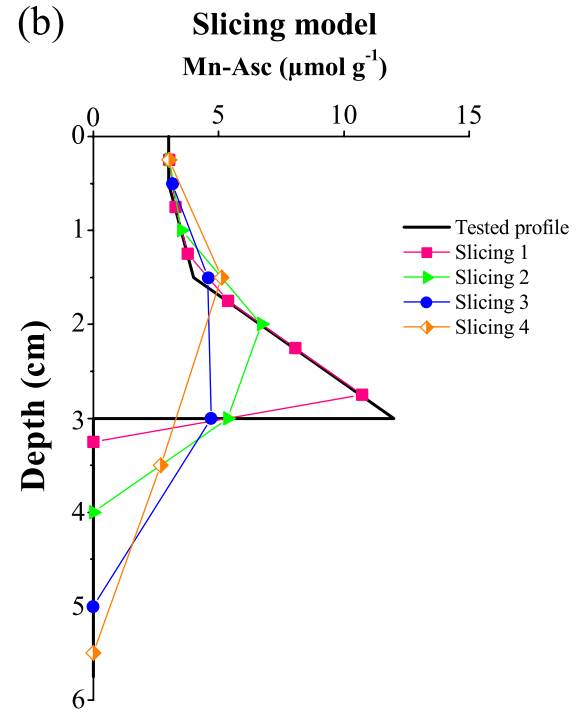

different for the slicing steps, whereas the overall inventory of Mnoxides is always the same. The Mn-oxide enrichment peak is smoothed because of slicing, and the disappearance depth of Mnoxides is not accurately assessed. Mn-oxides are not present below $3 \mathrm{~cm}$ depth; depending on the slicing step used, Mn-oxides disappear between 3.25 and $5.50 \mathrm{~cm}$ depth. In the slicing 4 profile, one data point shows Mn-oxides at a depth where they should not be present 
Table 7 Dissolved $\mathrm{Mn}^{2+}$ fluxes $\left(\mu \mathrm{mol} \mathrm{cm} \mathrm{cm}^{-2}\right.$ year $^{-1}$ )

\begin{tabular}{|c|c|c|c|c|c|c|c|c|c|c|}
\hline \multirow[t]{2}{*}{ Cruise } & \multirow[t]{2}{*}{ Date } & \multicolumn{9}{|l|}{ Station } \\
\hline & & $\begin{array}{l}\text { D } \\
(140 \mathrm{~m})\end{array}$ & $\begin{array}{l}C \\
(250 \mathrm{~m})\end{array}$ & $\begin{array}{l}\text { B } \\
(550 \mathrm{~m})\end{array}$ & $\begin{array}{l}\text { A } \\
(1,000 \mathrm{~m})\end{array}$ & $\begin{array}{l}\mathrm{F} \\
(1,250 \mathrm{~m})\end{array}$ & $\begin{array}{l}11 \\
(1,600 \mathrm{~m})\end{array}$ & $\begin{array}{l}\mathrm{H} \\
(2,000 \mathrm{~m})\end{array}$ & $\begin{array}{l}\text { I } \\
(2,800 \mathrm{~m})\end{array}$ & $\begin{array}{l}2 \\
(4,825 \mathrm{~m})\end{array}$ \\
\hline OB1 & Oct. 1997 & 7.67 & 1.10 & 1.54 & 0.24 & - & - & - & - & - \\
\hline OB2 & Jan. 1998 & 4.75 & 5.48 & 0.49 & 0.25 & 0.18 & - & - & - & - \\
\hline OB3 & Jun. 1998 & 3.65 & 6.94 & 0.48 & 0.14 & - & - & - & - & - \\
\hline OB4 & Jul. 1998 & 10.59 & 1.83 & 0.57 & 0.11 & - & - & - & - & - \\
\hline OB5 & Oct. 1998 & 8.40 & 5.48 & 0.35 & 0.22 & - & - & 0.26 & - & - \\
\hline OB6 & Dec. 1998 & 6.21 & 1.83 & 0.50 & 0.12 & - & - & - & - & - \\
\hline OB7 & Jan. 1999 & 10.59 & - & 0.56 & 0.26 & - & - & - & 0.19 & - \\
\hline OB8 & Apr. 1999 & 8.03 & - & 0.55 & - & - & - & - & - & - \\
\hline OB9 & Jun. 1999 & 5.11 & - & 0.38 & 0.22 & - & - & - & 1.06 & - \\
\hline OB10 & May 2000 & 3.65 & - & 0.32 & 0.38 & - & - & - & - & - \\
\hline OB11 & Apr. 2001 & 2.92 & - & - & - & - & - & - & - & - \\
\hline $\mathrm{SC} 1$ & Jun. 2001 & 3.65 & - & - & - & - & - & - & - & - \\
\hline $\mathrm{SC} 2$ & Sep. 2001 & 6.57 & - & - & - & - & - & - & - & - \\
\hline $1 \mathrm{FP}$ & Aug. 2003 & - & - & - & - & - & - & - & - & 0.22 \\
\hline $2 \mathrm{FP}$ & May 2004 & 2.92 & - & 0.22 & 0.15 & - & 0.19 & 0.26 & - & - \\
\hline $3 \mathrm{FP}$ & Aug. 2005 & 1.10 & 6.94 & - & 0.13 & 0.44 & - & 0.24 & - & - \\
\hline PECH1 & Jun. 2006 & 4.73 & - & 1.31 & 0.18 & - & - & 0.15 & - & - \\
\hline Average & - & 5.66 & 4.22 & 0.60 & 0.20 & 0.31 & 0.19 & 0.23 & 0.63 & 0.22 \\
\hline
\end{tabular}

continental shelf (Jouanneau et al. 1998b), and not the deeper zones. Nevertheless, the data discussed below argue against this explanation for these north/south gradients.

Because the inventories of $\mathrm{Mn}$ associated with the Mn$\mathrm{HCl}$ minus $\mathrm{Mn}$-Asc fractions are approx. constant, $\mathrm{Mn}$ (III, IV) oxides extracted by ascorbate largely control the Mn$\mathrm{HCl}$ levels. Manganese carbonate levels in these anoxic sediments (representing the major part of the $\mathrm{Mn}-\mathrm{HCl}$ minus Mn-Asc fractions) are very similar at the northern and southern stations (Fig. 6), with values very close to that of $2 \mu \mathrm{mol} \mathrm{Mn}$-Asc $\mathrm{g}^{-1}$ recorded in suspended particles in the Bay of Biscay waters. Because manganese is a conservative element (i.e. buried $\mathrm{Mn}-\mathrm{HCl}$ content would be equal to the content of settling detrital manganese oxides), it follows that input at the northern stations is not enriched in $\mathrm{Mn}$, compared to that at the southern stations.

To conclude, the shape of vertical profiles of particulate Mn changes with time. However, changes in the distribution of particulate $\mathrm{Mn}$ are low, and they can be attributed to patchiness and to the procedure of core sub-sampling. At a given station, inventories of Mn-oxide present in the upper sediment layer do not change significantly with time. This suggests that the quantity of diagenetic Mn-oxide that crosses the $\mathrm{Mn}(\mathrm{III}, \mathrm{IV})-\mathrm{Mn}$ (II) redox front due to burial is balanced by the upward flux of dissolved Mn(II). Integration of particulate $\mathrm{Mn}$ inventories enables us to compare the stations studied. The differences in Mn-oxide inventories would not be caused by variable sources of settling material. One possible explanation would be distinct combinations of sedimentation rate and benthic metabolism, which would maintain an Mn-rich layer at the northern stations in contact with North Atlantic deep water, and a less enriched layer at shallower stations.

\section{Diagenetic Mn(III,IV) oxide formation}

\section{Fluxes of dissolved Mn(II)}

Diagenetic Mn-oxide authigenesis results from the oxidative precipitation of dissolved $\mathrm{Mn}$ (II) that diffuses upwards from the anoxic sediments (Fig. 4). The flux of dissolved manganese in pore waters can be calculated (assuming transport by molecular diffusion) from the concentration gradients according to Fick's first law:

$J=\phi D_{s} \mathrm{~d} C / \mathrm{d} X$

where $J$ is the flux, $\phi$ the porosity, $\mathrm{d} C / \mathrm{d} X$ the concentration gradient, and $D_{\mathrm{s}}$ the bulk sediment diffusion coefficient corrected for tortuosity, i.e. $D_{\mathrm{s}}=D_{0} / \theta^{2}$ where $\theta$ is the tortuosity, and $D_{0}$ the diffusion coefficient in water (Berner 1980). $D_{0}$ values were obtained from Li and Gregory (1974), and $\theta^{2}$ is assumed to be equal to $1-\ln \left(\phi^{2}\right)$ (Boudreau 1996). Fluxes were calculated from the linear gradient of $\mathrm{Mn}^{2+}$ in the upper part of the anoxic zone. These gradients were smoothed, i.e. the narrow peaks of dissolved Mn presumably caused by sporadic bioturbation were averaged out (e.g. at station B). 
Fig. 6 Inventories of $\mathrm{Mn}$ extracted by $\mathrm{HCl}(\mathrm{Mn}-\mathrm{HCl}), \mathrm{Mn}$ extracted by ascorbate (MnAsc), and the difference between the inventories of $\mathrm{Mn}-\mathrm{HCl}$ and Mn-Asc vs. water depth at stations $\mathrm{D}, \mathrm{C}, \mathrm{B}, \mathrm{A}, \mathrm{F}, 11, \mathrm{H}, \mathrm{I}$ and 2
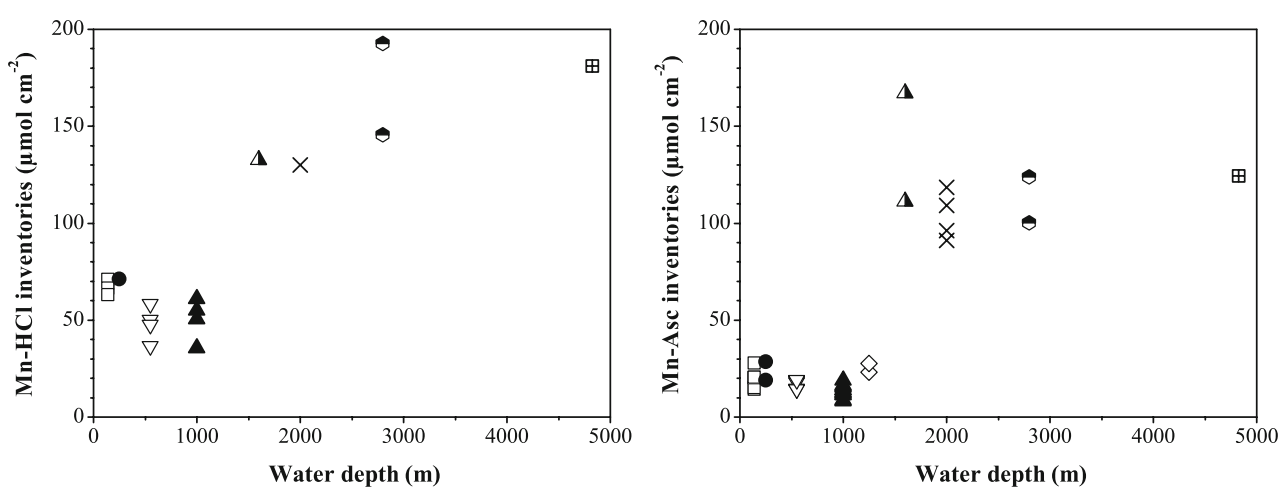

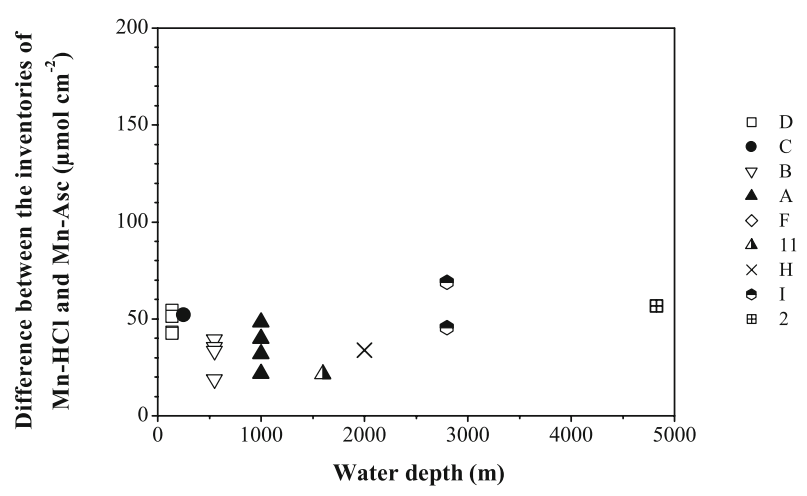

Bioturbated (shallower) stations Upward diffusive fluxes of dissolved $\mathrm{Mn}$ are highest $\left(>2 \mu \mathrm{mol} \mathrm{cm}{ }^{-2}\right.$ year $\left.^{-1}\right)$ at the shallowest stations D and C (Table 7). Flux values are not constant with time at a given station, indicating that nonsteady-state conditions influence $\mathrm{Mn}$ cycling at the redox front. Nevertheless, the values remain in the same order of magnitude.

The high flux values calculated at stations $\mathrm{D}$ and $\mathrm{C}$ can be explained by the presence of an $\mathrm{Mn}$ (II) peak observed below the oxic layer. In turn, the magnitude of this peak depends on the amount of Mn-oxides transported, and thus reduced, in the upper part of the anoxic layer. Dissolved Mn fluxes vary with time, probably because bioturbation is not a steady-state process at these stations at the timescale corresponding to the frequency of the cruises.

Less bioturbated (deeper) stations At the deepest stations, diffusive fluxes are less than $1 \mu \mathrm{mol} \mathrm{cm}{ }^{-2}$ year $^{-1}$ (Table 7). It should be noted that the $\mathrm{Mn}$ (II) concentration gradient is deduced from only two or three data points for each station. This is not enough to obtain sufficiently high precision for these flux calculations.

\section{Calculations of mass accumulation rates}

Because the content of settling detrital Mn-oxides $\left(<2 \mu \mathrm{mol} \mathrm{g}^{-1}\right)$ is low in terms of the total Mn-oxide pool, the enrichment recorded in the oxic layer is mostly of diagenetic origin, and not inherited from sedimenting particles (Fig. 4). Therefore, we can assume that manganese oxide inventories result largely from the oxidation of dissolved $\mathrm{Mn}$ (II) that diffuses from below. The progressive development of an Mn-enriched layer in the oxic zone, i.e. the gradual increase with time of the Mn-Asc inventory, is a transient process that has not been observed at the studied stations. When the Mn-enriched layer reaches steady state, the burial flux of diagenetic Mn-oxides towards the anoxic zone must be essentially equal to the upward flux of $\mathrm{Mn}$ (II) (Fig. 4). Therefore, we can use this average upward flux of $\mathrm{Mn}(\mathrm{II})(J)$ and the inventory of $\mathrm{Mn}(\mathrm{III}, \mathrm{IV})(I)$ to calculate the residence time $T$ of Mn-oxides in the oxic layer, according to

$T=T / J$

Calculations of $T$ were performed for the deeper stations, for which Mn-oxide inventories can be considered to be essentially constant. $T$ is $28,66,82,747,460,179$ and 559 years for stations $\mathrm{B}, \mathrm{A}, \mathrm{F}, 11, \mathrm{H}, \mathrm{I}$ and 2 respectively (Table 8). This corresponds to the time necessary for Mnoxides to move out of the oxic zone, due to burial. $\mathrm{Mn}$ is a proxy for the time needed to bury, below the oxic front, a pool of particles included in the oxic layer. Thus, $T$ is equivalent to the time required for the accumulation of particles contained in the oxic layer. Therefore, the distribution of Mn species can be used to determine mass 
Table 8 Results and parameters required to calculate residence time $T$ (see text)

\begin{tabular}{|c|c|c|c|c|c|c|}
\hline Station & $\begin{array}{l}\text { Average } \\
\mathrm{Mn}^{2+} \text { flux } \\
\left(\mu \mathrm{mol} \mathrm{cm} \mathrm{cm}^{-2}\right. \\
\left.\text { year }{ }^{-1}\right)\end{array}$ & $\begin{array}{l}\text { I: average } \\
\text { Mn-Asc inventory } \\
\left.(\mu \mathrm{mol} \mathrm{cm})^{-2}\right)\end{array}$ & $\begin{array}{l}T \text { : residence } \\
\text { time of Mn-Asc } \\
\text { (years) }\end{array}$ & $\begin{array}{l}M \text { : mass of the } \\
\text { oxic layer } \\
\left(\mathrm{mg} \mathrm{cm}^{-2}\right)\end{array}$ & $\begin{array}{l}\text { Accumulation rate } \\
\text { deduced from } \mathrm{Mn} \\
\left(\mathrm{mg} \mathrm{cm}^{-2} \text { year }^{-1}\right)\end{array}$ & $\begin{array}{l}\text { Accumulation rate } \\
\text { deduced from }{ }^{210} \mathrm{~Pb}_{\mathrm{xs}} \\
\left(\mathrm{mg} \mathrm{cm}^{-2} \text { year }^{-1}\right)\end{array}$ \\
\hline $\mathrm{B}(550 \mathrm{~m})$ & 0.60 & 17.0 & 28 & 1,517 & 54 & 80 \\
\hline $\mathrm{A}(1,000 \mathrm{~m})$ & 0.20 & 13.2 & 66 & 2,270 & 34 & 36 \\
\hline $\mathrm{F}(1,250 \mathrm{~m})$ & 0.31 & 25.3 & 82 & 3,565 & 44 & - \\
\hline $11(1,500 \mathrm{~m})$ & 0.19 & 139.1 & 747 & 5,073 & 7 & - \\
\hline $\mathrm{H}(2,000 \mathrm{~m})$ & 0.23 & 103.7 & 460 & 4,309 & 9 & $14\left(7^{\mathrm{c}}\right)$ \\
\hline I $(2,800 \mathrm{~m})$ & 0.63 & 112.0 & 179 & 3,287 & 18 & $\begin{array}{l}17 \\
16^{\mathrm{a}} \\
18^{\mathrm{b}}\end{array}$ \\
\hline $2(4,825 \mathrm{~m})$ & 0.22 & 124.5 & 559 & 8,418 & 15 & 20 \\
\hline 20 & 2.25 & 27.7 & 12 & 1,352 & 110 & $113^{\mathrm{d}}$ \\
\hline 25 & 3.49 & 68.6 & 20 & 2,279 & 116 & $175^{\mathrm{d}}$ \\
\hline $\mathrm{PB}(3,890 \mathrm{~m})$ & 1.53 & 276.8 & 181 & 1,100 & 6 & $7^{\mathrm{e}}$ \\
\hline $\begin{array}{l}\text { BT C } \\
\quad(980 \mathrm{~m})\end{array}$ & 0.49 & 208.0 & 421 & 6,323 & 15 & 40 \\
\hline
\end{tabular}

Accumulation rates are maximum values deduced either from ${ }^{210} \mathrm{~Pb}_{\mathrm{xs}}$ values or from the distribution of Mn compounds (see text for details)

${ }^{a}$ Data from sediment trap at MS2 site, 3,000 $\mathrm{m}$ water depth, close to station I (ECOFER program, Heussner et al. 1999)

${ }^{\mathrm{b}}$ Data estimated with ${ }^{210} \mathrm{~Pb}$ budget at MS2 site, 3,000 m water depth, close to station I (ECOFER program, Radakovitch and Heussner 1999)

${ }^{\mathrm{c}}$ Data from sediment traps (Schmidt, unpublished data)

${ }^{\mathrm{d}}$ Data from sediment traps, St. Lawrence estuary (Silverberg et al. 1986)

${ }^{\mathrm{e}}$ Data from sediment traps, Panama Basin (Honjo 1982)

accumulation rate. The method consists of calculating $T$, and applying this time according to

$$
\operatorname{MAR}=M / T
$$

where MAR is the mass accumulation rate, and $M$ the mass of particles present in the oxic layer. Here, $M$ was calculated for a projected area of $1 \mathrm{~cm}^{2}$ by integration of the dry mass of particles deduced from particle volumes (i.e. $1-\phi$ ), and a mean particle specific density of 2.65 (Berner 1980). We used this Mn method to estimate the MAR of those stations for which the Mn-oxide inventory was included largely within the oxic layer, i.e. the deeper stations (Table 8). Moderate bioturbation, which would redistribute Mn-oxide in the oxic layer, does not affect the concept of our model. The calculated values are between 34 and $54 \mathrm{mg} \mathrm{cm}^{-2}$ year $^{-1}$ at the stations with low Mn-Asc
Fig. 7 Vertical distributions of particulate Mn extracted by ascorbate (Mn-Asc, $\mu \mathrm{mol} \mathrm{g}{ }^{-1}$ ), dissolved $\mathrm{Mn}(\mathrm{II})\left(\mathrm{Mn}^{2+}, \mu \mathrm{M}\right)$, ${ }^{210} \mathrm{~Pb}$ excess activity $\left({ }^{210} \mathrm{~Pb}_{\mathrm{xs}}\right.$, $\mathrm{Bq} \mathrm{kg}^{-1}$ ) and porosity (\%) at station BT C in the Mediterranean Sea $\left(980 \mathrm{~m}, 42^{\circ} 43^{\prime} 18 \mathrm{~N}\right.$, $\left.4^{\circ} 46^{\prime} 58 \mathrm{E}\right)$

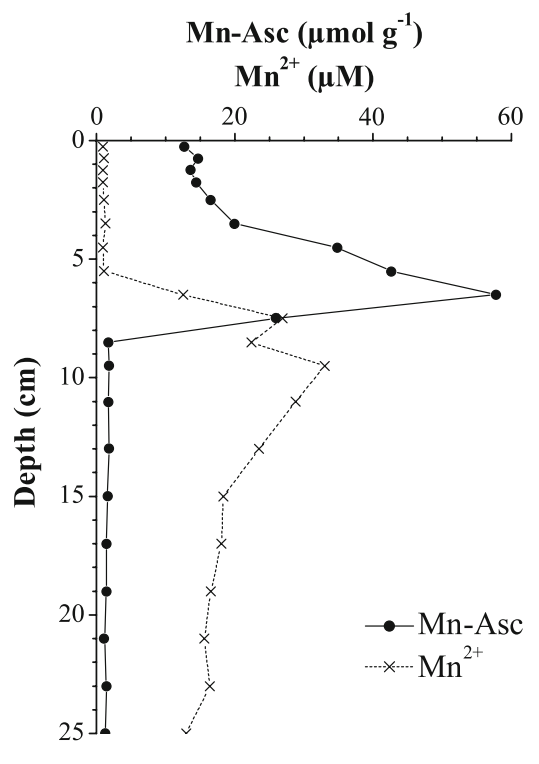


inventories (B, A and F), and between 18 and $7 \mathrm{mg} \mathrm{cm}^{-2}$ year $^{-1}$ at the deeper stations.

\section{Validation of the method}

We have attempted to validate the Mn method with other independent data from sediment traps and ${ }^{210} \mathrm{~Pb}_{\mathrm{xs}}$ profiles. Sediment trap data are available from the ECOFER program, for the Cap Ferret canyon at the site MS2 located close to our station I (2,800 m), and from the FORCLIM program, at our station H. Site MS2 at 3,000 m water depth provided a mean MAR of $16 \mathrm{mg} \mathrm{cm}^{-2}$ year $^{-1}$ (Heussner et al. 1999). Radakovitch and Heussner (1999) obtained a value of $18 \mathrm{mg}$ $\mathrm{cm}^{-2}$ year ${ }^{-1}$ at the same site, using a budget of ${ }^{210} \mathrm{~Pb}$. From sediment trap data, Schmidt (unpublished data) obtained a mass accumulation rate of $7 \mathrm{mg} \mathrm{cm}{ }^{-2}$ year $^{-1}$ at station $\mathrm{H}$. These values are in excellent agreement with those obtained with the $\mathrm{Mn}$ method at stations I and $\mathrm{H}-18$ and $9 \mathrm{mg} \mathrm{cm}^{-2}$ year $^{-1}$ respectively (Table 8 ).

Mass accumulation rates estimated with ${ }^{210} \mathrm{~Pb}_{\mathrm{xs}}$ in sediments collected at stations $\mathrm{B}, \mathrm{A}, \mathrm{H}, \mathrm{I}$ and 2 are remarkably close to values deduced from the distribution of Mn phases (Table 8), although these represent independent calculations. At stations A and I, Mn values are within $10 \%$ of ${ }^{210} \mathrm{~Pb}_{\mathrm{xs}}$ values. At stations $\mathrm{H}$ and 2 , they are within $35 \%$. The limited number of dissolved Mn profiles at these stations could explain this greater difference. Because pore water $\mathrm{Mn}^{2+}$ levels can be unstable close to the redox front, any $\mathrm{Mn}^{2+}$ profile in a transient state would cause deviations from the overall flux representative of processes at steady state. The difference between the Mn method and the ${ }^{210} \mathrm{~Pb}_{\mathrm{xs}}$ method is even greater at station $\mathrm{B}$ (Table 8), where the ${ }^{210} \mathrm{~Pb}_{\mathrm{xs}}$-based MAR is higher, probably because bioturbation significantly affects the slope of the ${ }^{210} \mathrm{~Pb}_{\mathrm{xs}}$ profile, but not the Mn-oxide inventories.

\section{Application to other environments}

In order to better validate the Mn method for MAR calculation, we applied it to sedimentary environments for which published profiles of Mn species exist, together with MAR measured alternatively. Porosity data are necessary to calculate the inventories of Mn-oxide. This parameter is often lacking in the articles we examined. A complete set of data has been found for sediments from the outer St. Lawrence estuary (Sundby et al. 1981; Silverberg et al. 1986; Silverberg and Sundby 1990), and from the Panama Basin (Honjo 1982; Aller 1990; Aller et al. 1998). Here again, the mass accumulation rates obtained with the Mn method are remarkably close to those based on sediment trap data for both locations (Table 8).

Finally, we tested the method using data from sediment cores we collected in September 2006 in the western
Mediterranean Sea, at $980 \mathrm{~m}$ water depth (Fig. 7). The upward diffusive flux of dissolved Mn obtained from this single profile is $0.49 \mu \mathrm{mol} \mathrm{cm}{ }^{-2}$ year $^{-1}$. The time $T$ to form the inventory of Mn-Asc in the oxic layer with this flux would be 421 years. The particulate material $M$ contained in the Mn-oxide-enriched layer is $6,323 \mathrm{mg} \mathrm{cm}^{-2}$, corresponding to a deduced MAR of $15 \mathrm{mg} \mathrm{cm}^{-2} \mathrm{year}^{-1}$. The ${ }^{210} \mathrm{~Pb}_{\mathrm{xs}}$ profile gives a value of $40 \mathrm{mg} \mathrm{cm}^{-2}$ year $^{-1}$. The presence of a bioturbation-induced mixed layer at the top of the core (Fig. 7), like at station B in the Bay of Biscay, or non-steady-state conditions probably explains this difference between the two MAR estimates.

To conclude, steady-state particulate $\mathrm{Mn}$ inventories and fluxes of dissolved Mn make it possible to estimate the residence time for diagenetic Mn-oxides in the oxic layer. By extension, the distribution of $\mathrm{Mn}$ species enables us to calculate mass accumulation rates. At the stations studied in the Bay of Biscay, mass accumulation rates obtained from the Mn method fit well with values obtained from the conventional ${ }^{210} \mathrm{~Pb}_{\mathrm{xs}}$ method and sediment trap data. This indicates that the diagenesis of $\mathrm{Mn}$ in these environments is at steady state at the multi-annual timescale. Compared to radionuclide techniques of determining mass accumulation rates, the analytical expense of the Mn method is high, including pore water as well as ascorbate extractions and analyses. It is, however, a suitable alternative approach, and could prove useful where geochemical investigations are anyhow being, or have been undertaken.

Acknowledgements We thank R.C. Aller for providing data of the Panama Basin. We would like to express our gratitude to the numerous students who contributed to the laboratory work between 1997 and 2006, notably K. Dedieu, F. Desmazes, A.C. Lemarie and G. Pruvost. The constructive comments of two anonymous reviewers and the journal editor helped to improve the manuscript. This research was funded by the projects OXYBENT and FORAMPROX of the program PROOF of the Institut National des Sciences de l'Univers, and the program ANR05-FORCLIM. It is a contribution of the UMR 5805 EPOC.

\section{References}

Aller RC (1980) Diagenetic processes near the sediment-water interface of Long Island Sound. II. Fe and Mn. Adv Geophys 22:351-415

Aller RC (1990) Bioturbation and manganese cycling in hemipelagic sediments. Philos Trans R Soc Lond 331:51-68

Aller RC (1994) The sedimentary Mn cycle in Long Island Sound: its role as intermediate oxidant and the influence of bioturbation, $\mathrm{O}_{2}$, and $\mathrm{C}_{\text {org }}$ flux on diagenetic reaction balances. J Mar Res 52:259-295

Aller RC, Aller JY (1998) The effect of biogenic irrigation intensity and solute exchange of diagenetic reaction rates in marine sediments. J Mar Res 56:905-936

Aller RC, Hall POJ, Rude PD, Aller JY (1998) Biogeochemical heterogeneity and suboxic diagenesis in hemipelagic sediments of the Panama Basin. Deep-Sea Res 45:133-165 
Anschutz P, Sundby B, Lefrancois L, Luther GW III, Mucci A (2000) Interactions between metal oxides and species of nitrogen and iodine in bioturbated marine sediments. Geochim Cosmochim Acta 64:2751-2763

Anschutz P, Jorissen FJ, Chaillou G, Abu-Zied R, Fontanier C (2002) Recent turbidite deposition in the eastern Atlantic: early diagenesis and biotic recovery. J Mar Res 60:835-854

Anschutz P, Dedieu K, Desmazes F, Chaillou G (2005) Speciation, oxidation state, and reactivity of particulate manganese in marine sediments. Chem Geol 218:265-279

Berner RA (1980) Early diagenesis: A theoretical approach. Princeton University Press, Princeton, NJ

Boudreau BP (1986a) Mathematics of tracer mixing in sediments: I. Spatially-dependent, diffusive mixing. Am J Sci 286:161-198

Boudreau BP (1986b) Mathematics of tracer mixing in sediments: II. Nonlocal mixing and biological conveyor-belt phenomena. Am J Sci 286:199-238

Boudreau BP (1996) The diffusive tortuosity of fine-grained unlithified sediments. Geochim Cosmochim Acta 60:3139-3142

Boudreau BP (1998) Mean mixed depth of sediments: the wherefore and the why. Limnol Oceanogr 43:524-526

Burdige DJ (1993) The biogeochemistry of manganese and iron reduction in marine sediments. Earth Sci Rev 35:249-284

Burdige DJ, Gieskes JM (1983) A pore water/solid phase diagenetic model for manganese in marine sediments. Am J Sci 283:29-47

Burdige DJ, Alperin MJ, Homstead J, Martens CS (1992) Effects of manganese oxide mineralogy on microbial and chemical manganese reduction. Geomicrobiol J 10:27-48

Canfield DE, Thamdrup B, Hansen JW (1993) The anaerobic degradation of organic matter in Danish coastal sediments: iron reduction, manganese reduction and sulfate reduction. Geochim Cosmochim Acta 57:3867-3883

Chaillou G, Anschutz P, Lavaux G, Schäfer J, Blanc G (2002) The distribution of $\mathrm{Mo}, \mathrm{U}$, and $\mathrm{Cd}$ in relation to major redox species in muddy sediments of the Bay of Biscay. Mar Chem 80:41-59

Chaillou G, Schäfer J, Anschutz P, Lavaux G, Blanc G (2003) The behaviour of arsenic in muddy sediments of the Bay of Biscay (France). Geochim Cosmochim Acta 67:2993-3003

Chaillou G, Anschutz P, Lavaux G, Blanc G (2006) Rare earth elements in the modern sediments of the Bay of Biscay (France). Mar Chem 100:39-52

Dellwig O, Bosselmann K, Kölsch S, Hentscher M, Hinrichs J, Böttcher ME, Reuter R, Brumsack HJ (2007) Sources and fate of manganese in a tidal basin of the German Wadden Sea. J Sea Res 57:1-18

Etcheber H, Relexans JC, Beliard M, Weber O, Buscail R, Heussner S (1999) Distribution and quality of sedimentary organic matter on the Aquitanian margin (Bay of Biscay). Deep-Sea Res II 46:2249-2288

Fontanier C, Jorissen FJ, Licari L, Alexandre A, Anschutz P, Carbonel P (2002) Live benthic foraminiferal faunas from the Bay of Biscay: faunal density, composition, and microhabitats. Deep-Sea Res 49:751-785

Fontanier C, Jorissen FJ, Chaillou G, David C, Anschutz P, Lafon V (2003) Seasonal and interannual variability of benthic foraminiferal faunas at $550 \mathrm{~m}$ depth in the Bay of Biscay. Deep-Sea Res 50:457-494

Fontanier C, Jorissen FJ, Chaillou G, Anschutz P, Grémare A, Griveaud C (2005) Live foraminiferal faunas from a $2800 \mathrm{~m}$ deep lower canyon station from the Bay of Biscay: faunal response to focusing of refractory organic matter. Deep-Sea Res 52:1189-1227

Fontanier C, Jorissen F, Anschutz P, Chaillou G (2006) Seasonal variability of benthic foraminiferal faunas at $1000 \mathrm{~m}$ depth in the Bay of Biscay. J Foram Res 36:61-76

Froehlich PN, Klinkhammer GP, Bender ML, Luedtke NA, Heath GR, Cullen D, Dauphin P, Hammond D, Hartman B, Maynard V (1979) Early oxidation of organic matter in pelagic sediments of the eastern equatorial Atlantic: suboxic diagenesis. Geochim Cosmochim Acta 43:1075-1090

Gehlen M, Rabouille C, Ezat U, Guidi-Guilvard LD (1997) Drastic changes in deep-sea sediment porewater composition induced by episodic input of organic matter. Limnol Oceanogr 42:980-986

Gobeil C, Macdonald RW, Sundby B (1997) Diagenetic separation of cadmium and manganese in suboxic continental margin sediments. Geochim Cosmochim Acta 61:4647-4654

Goldberg ED, Koide M (1962) Geochronological studies of deep sea sediments by the ionium/thorium method. Geochim Cosmochim Acta 26:417-450

Grémare A, Guttierez D, Anschutz P, Amouroux JM, Deflandre B, Vétion G (2005) Spatio-temporal changes in totally and enzymatically hydrolysable amino acids of superficial sediments from three contrasted areas. Prog Oceanogr 65:89-111

Grill EV (1978) The effects of sediment-water exchange on manganese deposition and nodule growth in Jervis Inlet, British Columbia. Geochim Cosmochim Acta 42:485-494

Heussner S, Durrieu de Madron X, Radakovitch O, Beaufort L, Biscaye PE, Carbonne J, Delsaut N, Etcheber H, Monaco A (1999) Spatial and temporal patterns of downward particle fluxes on the continental slope of the Bay of Biscay (northeastern Atlantic). Deep-Sea Res II 46:2101-2146

Holdren GR Jr, Bricker OP III, Matisoff G (1975) A model for the control of dissolved manganese in the interstitial waters of Chesapeake Bay. In: Church TM (ed) Marine chemistry in the coastal environment. Am Chem Soc Symp 18:364-381

Honjo S (1982) Seasonality and interaction of biogenic and lithogenic particulate flux at the Panama Basin. Science 218:883-884

Hulth S, Aller RC, Gilbert F (1999) Coupled anoxic nitrification/ manganese reduction in marine sediments. Geochim Cosmochim Acta 63:49-66

Hyacinthe C, Van Cappellen P (2004) An authigenic iron phosphate phase in estuarine sediments: composition, formation and chemical reactivity. Mar Chem 91:227-251

Hyacinthe C, Anschutz P, Carbonel P, Jouanneau J-M, Jorissen FJ (2001) Early diagenetic processes in the muddy sediments of the Bay of Biscay. Mar Geol 177:111-128

Jahnke RA, Craven DB, McCorkle DC, Reimers CE (1997) $\mathrm{CaCO}_{3}$ dissolution in California continental margin sediments: the influence of organic matter remineralization. Geochim Cosmochim Acta 61:3587-3604

Jakobsen R, Postma D (1989) Formation and solid solution behavior of $\mathrm{Ca}$ rhodochrosites in marine muds of the Baltic deeps. Geochim Cosmochim Acta 53:2639-2648

Jouanneau J-M, Garcia C, Oliveira A, Rodrigues A, Dias JA, Weber O (1998a) Dispersal and deposition of suspended sediment on the shelf off the Tagus and Sado estuaries, S.W. Portugal. Prog Oceanogr 42:233-257

Jouanneau J-M, Weber O, Grousset FE, Thomas B (1998b) Pb, Zn, Cs, Sc and rare earth elements as tracers of the Loire and Gironde particles on the Biscay shelf (SW France). Oceanol Acta 21:233-241

Katsev S, Sundby B, Mucci A (2006) Modeling vertical excursions of the redox boundary in sediments: application to deep basins of the Arctic Ocean. Limnol Oceanogr 51:1581-1593

Kostka JE, Luther GW III (1994) Partitioning and speciation of solid phase iron in saltmarsh sediments. Geochim Cosmochim Acta 58:1701-1710

Lecroart P, Schmidt S, Anschutz P, Jouanneau JM (2007) Modeling sensitivity of biodiffusion coefficient to seasonal bioturbation. J Mar Res 65:417-440

Li Y-H, Gregory S (1974) Diffusion of ions in sea water and in deepsea sediments. Geochim Cosmochim Acta 38:703-714

Luther GW III, Popp JI (2002) Kinetics of the abiotic reduction of polymeric manganese dioxide by nitride: an anaerobic nitrification reaction. Aquat Geochem 18:15-36 
Luther GW III, Sundby B, Lewis BL, Brendel PJ, Silverberg N (1997) Interactions of manganese with the nitrogen cycle: alternative pathways to dinitrogen. Geochim Cosmochim Acta 61:4043-4052

Meysman FJR, Boudreau BP, Middelburg JJ (2003) Relations between local, nonlocal, discrete and continuous models of bioturbation. J Mar Res 61:391-410

Middelburg JJ, De Lange GJ, Van Der Weijden CH (1987) Manganese solubility control in marine pore waters. Geochim Cosmochim Acta 51:759-763

Mucci A (1988) Manganese uptake during calcite precipitation from seawater: conditions leading to the formation of a pseudokutnahorite. Geochim Cosmochim Acta 52:1859-1868

Mucci A (2004) The behavior of mixed Ca-Mn carbonates in water and seawater: controls of manganese concentrations in marine porewaters. Aquat Geochem 10:139-169

Murray JW (1975) The interaction of metal ions at the manganese dioxide-solution interface. Geochim Cosmochim Acta 39:505-519

Myers CR, Nealson KH (1988a) Bacterial manganese reduction and growth with manganese oxide as the sole electron acceptor. Science 240:1319-1321

Myers CR, Nealson KH (1988b) Microbial reduction of manganese oxides: interactions with iron and sulfur. Geochim Cosmochim Acta 52:2727-2732

Pedersen TF, Price NB (1982) The geochemistry of manganese carbonate in Panama Basin sediments. Geochim Cosmochim Acta 46:59-68

Post JE (1999) Manganese oxide minerals: crystal structures and economic and environmental significance. Proc Natl Acad Sci USA 96:3447-3454

Radakovitch O, Heussner S (1999) Fluxes and budget of ${ }^{210} \mathrm{~Pb}$ on the continental margin of the Bay of Biscay (northeastern Atlantic). Deep-Sea Res II 46:2175-2203

Schippers A, Jørgensen BB (2001) Oxidation of pyrite and iron sulfide by manganese dioxide in marine sediments. Geochim Cosmochim Acta 65:915-922

Schmidt S, Jouanneau J-M, Weber O, Lecroart P, Radakovitch O, Gilbert F, Jézéquiel D (2007) Sedimentary processes in the Thau
Lagoon (France): from seasonal to century time scales. Estuar Coastal Shelf Sci 72:534-542

Silverberg N, Sundby B (1990) Sediment-water interaction and early diagenesis in the Laurentian Trough. In: El-Sabh MI, Silverberg $\mathrm{N}$ (eds) Oceanography of a large-scale estuarine system: the St. Lawrence. vol. 39. Springer, Berlin Heidelberg New York, pp 203-238 Coastal and Estuarine Studies

Silverberg N, Nguyen HV, Delibrias G, Koide M, Sundby B, Yokoyama Y, Chesselet R (1986) Radionuclide profiles, sedimentation rates, and bioturbation in modern sediments of the Laurentian Trough, Gulf of St. Lawrence. Oceanol Acta 9:285290

Stone AT (1987) Microbial metabolites and the reductive dissolution of manganese oxides: oxalate and pyruvate. Geochim Cosmochim Acta 51:919-925

Stumm W, Morgan JJ (1996) Aquatic chemistry: Chemical equilibria and rates in natural waters, 3rd edn. Wiley, New York

Suess E (1979) Mineral phases formed in anoxic sediments by microbial decomposition of organic matter. Geochim Cosmochim Acta 43:339-341

Sundby B (2006) Transient state diagenesis in continental margin muds. Mar Chem 102:2-12

Sundby B, Silverberg N (1985) Manganese fluxes in the benthic boundary layer. Limnol Oceanogr 30:374-382

Sundby B, Silverberg N, Chesselet R (1981) Pathways of manganese in an open estuarine system. Geochim Cosmochim Acta 45:293-307

Thamdrup B, Glud RN, Hansen JW (1994) Manganese oxidation and in situ manganese fluxes from a coastal sediment. Geochim Cosmochim Acta 58:2563-2570

Thomson J, Higgs NC, Hydes DJ, Colley S, Wilson TRS (1986) The behaviour of manganese in Atlantic carbonate sediments. Geochim Cosmochim Acta 50:1807-1818

Trouwborst RE, Clement BG, Tebo BM, Glazer BT, Luther GW III (2006) Soluble Mn(III) in suboxic zones. Science 313:1955-1957

van der Zee C, van Raaphorst W, Epping E (2001) Absorbed $\mathrm{Mn}^{2+}$ and $\mathrm{Mn}$ redox cycling in Iberian continental margin sediments (northeast Atlantic Ocean). J Mar Res 59:133-166 